\title{
On the Evolution of Social Development in the British Sudan A Comparative Study of the Gezira and Zande Cotton-Growing Schemes
}

Joseph M. Snyder

West Virginia University

Follow this and additional works at: https://researchrepository.wvu.edu/etd

\section{Recommended Citation}

Snyder, Joseph M., "On the Evolution of Social Development in the British Sudan A Comparative Study of the Gezira and Zande Cotton-Growing Schemes" (2011). Graduate Theses, Dissertations, and Problem Reports. 4792.

https://researchrepository.wvu.edu/etd/4792

This Thesis is protected by copyright and/or related rights. It has been brought to you by the The Research Repository @ WVU with permission from the rights-holder(s). You are free to use this Thesis in any way that is permitted by the copyright and related rights legislation that applies to your use. For other uses you must obtain permission from the rights-holder(s) directly, unless additional rights are indicated by a Creative Commons license in the record and/ or on the work itself. This Thesis has been accepted for inclusion in WVU Graduate Theses, Dissertations, and Problem Reports collection by an authorized administrator of The Research Repository @ WVU. For more information, please contact researchrepository@mail.wvu.edu. 
On the Evolution of Social Development in the British Sudan A Comparative Study of the Gezira and Zande Cotton-Growing Schemes

Joseph M. Snyder

\author{
Thesis submitted to the \\ Eberly College of Arts and Sciences \\ at West Virginia University \\ in partial fulfillment of the requirements \\ for the degree of
}

\author{
Master of Arts \\ in \\ Modern African History
}
Robert Maxon, Ph.D., Chair
Joseph M. Hodge, Ph.D.
Mark B. Tauger, Ph.D.

Department of History
Morgantown, West Virginia
2011

Keywords: Gezira; Zande; Sudan; Cotton-Growing; Schemes 


\section{ABSTRACT \\ On the Evolution of Social Development in the British Sudan A Comparative Study of the Gezira and Zande Cotton-Growing Schemes}

\section{Joseph M. Snyder}

By the early 1950s, two-thirds of the manpower in the British Colonial Service - some 10,000 out of 15,000 expatriates - was concentrated in Africa. The total disbursements on research showed the same Africanist bias: fifty-eight percent of the research money spent between 1940 and 1961 went into British African territories. These facts are indicative not only of the obvious - the massive investment obliged by planned decolonization - but also of the more opaque and protean: the influence of Lord Hailey's African survey, begun in the late 1930s, which culminated in his Native Administration and Political Development in Tropical Africa. Hailey's signally-important survey revolutionized imperial ideology towards Africa by shifting the objectives of the colonial administration from responsibility for law and order to concern for social life and standards of living of the indigenous population.

My paper examines this sweeping ideological "shift" - not only its evolution, but also the set of colonial values and beliefs that informed the designs of its predecessors. To create a legible framework for this discussion, I have couched my study within a comparative analysis of the two largest and most ambitious development programs introduced by the British Colonial Government in the Sudan: the Gezira and Zande Schemes, projects with rather different administrative lineages. An understanding of the contrasts between these two projects is important for a number of reasons. Firstly, and practically-speaking, it is difficult to atomize imperial policy into the constituent precipitating events that gave rise to ideological divergences in Africa during the colonial period - the "shift" mentioned above - and, should that considerable task be accomplished, the theoretical understanding of such complex and mutually supporting variables is rather more daunting without an examination of how such relations and variables play themselves out on the ground as specific practices. Secondly, the historiography of the British Sudan is curiously absent a direct comparative study of these two undertakings an eyebrow-raising oversight when it is considered that such an analysis would go a long way toward understanding not only the evolution of social development within the essentially fluid imperial schemata of the late-colonial period, but also help to contextualize events which would happen much later, such as the Sudanese Civil War. 


\section{TABLE OF CONTENTS}

Chapter 1: Introduction .................................................................................... 1

Chapter 2: The Law and Order Empire ......................................................................

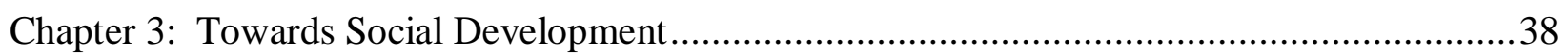

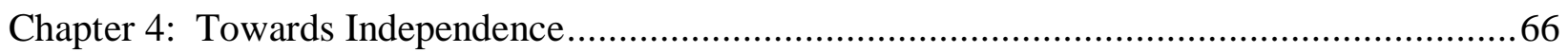

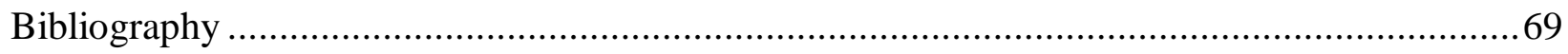




\section{Chapter One: \\ Introduction}

In 1947, after nearly a century of rule under the Raj, India gained its independence from the British Empire. But in the tumult of accelerated decolonization, something cataclysmic happened: the Great Partition. The wake of the great bifurcation of India and Pakistan consumed the Subcontinent's Muslim and Hindu populations in a white-hot fire of ethnicized violence. The Crown Jewel turned to charnel house.

Thousands of miles away in British Africa something rather different was happening; a revolution of sorts. Not surely of armed rebellions or of insurgents straining against the imperial yoke, but one of ideas. For, by the 1950s, British Africa was no longer eclipsed by the Raj and found itself suddenly awash with imperial largesse. As J.M. Lee has observed, some two-thirds of the manpower in the British Colonial Service, representing a sizable shift (about 10,000 out of 15,000 expatriates) in the pre-War distribution of personnel, became concentrated in Africa during this time. The total disbursements on research showed a similar Africanist bias: 58 percent of the research money spent between 1940 and 1961 went into British African territories. The imperial periphery, it seemed, had become its center. ${ }^{1}$

But these statistics tell of something more than just an Empire re-orienting itself, something larger than the massive investment obliged by planned decolonization. They speak, rather, to something far more opaque and protean and fundamental: a revolution in imperial ideology - one that started with a survey. A grand survey, to be sure, but one that sought to answer a beguilingly simple question: Just what did the Empire know about its empire? The answer to this question came in 1938 when the Royal Institute of International Affairs at Chatham House published what L.S. Amery mockingly called its "pachyderm": the African

\footnotetext{
${ }^{1}$ J.M. Lee, Colonial Development and Good Government (Oxford: Clarendon Press, 1967), 86.
} 
Survey. ${ }^{2}$ The end result of five years of scientific research and field work, what the Survey found could have surprised few people: the British, it seemed, knew rather little about the realm they administered. ${ }^{3}$ The man we have to thank for this singular revelation - the man behind the Survey's voluminous output - is William Malcolm Hailey, $1^{\text {st }}$ Baron Hailey.

Root and branch, Hailey was the very quintessence of the British Colonial Service. A scholar at Corpus Christi College in Oxford who took a degree in the "Greats," he was elected to the Indian Civil Service (I.C.S.) in 1894. Soon after, he was posted to the Punjab, where he took up what would become a singular, ruling - and, arguably, defining - passion throughout his long career: the great irrigation schemes that transformed vast deserts into massive corn granaries. A rugged man who reveled in the self-imposed discipline of long rides and long walks and cherished a lifelong affinity for camels, he was, like Richard Burton, that most curious product of the Victorian Age: the adventurer, innovator, and, for the fainting couch class, romantic ideal. ${ }^{4}$ He was possessed of an innate robustness, which served him well, particularly on his survey missions of the Indian deserts where he sought out nomads to assess and negotiate their compensation as the British Leviathan extended development into the Subcontinent's interior. In time, he became Governor of the Punjab and, finally, in his last posting before retirement, Governor of the United Provinces. After more than three decades in its service, it should come as no great surprise that Hailey's was a view of political development derived largely from his experiences as a part of the I.C.S. ${ }^{5}$ And it would prove the launching pad of his second career.

\footnotetext{
${ }^{2}$ Joseph M. Hodge, Triumph of the Expert: Agrarian Doctrines of Development and the Legacies of British Colonialism (Athens: Ohio University Press, 2007), 138 and K.D.D. Henderson, The Making of the Modern Sudan: The Life and Letters of Sir Douglas Newbold, K.B.E. (London: Faber and Faber Limited, 1953), 285.

${ }^{3}$ Lee, Colonial Development, 43 . The study group that sponsored Hailey's survey and the review of scientific research by E.B. Worthington, began work in 1933. It is worth noting that the survey was funded by the Carnegie Corporation of New York.

${ }^{4}$ Frederick Pedler, "The Rt. Hon. Lord Hailey, OM, GCSI, GCMG, GCIE: A Personal Appreciation," African Affairs 68, No. 273 (1969): 344, http://www.jstor.org.

${ }^{5}$ Lee, Colonial Development, 38.
} 
Upon his retirement from the I.C.S., Hailey was raised to a peerage of the Realm and, in time, was persuaded by Lord Lothian to undertake a task with considerable implications for the future of the Empire: the directorship of the African Research Survey. ${ }^{6}$ The great ideological foundation of the survey had been laid some six years before when General J.C. Smuts delivered his Rhodes Memorial Lecture at Oxford in 1929. In it, the "quite indefatigable" Smuts "pointed out that Africa was developing under the control of a number of European powers, that different and often conflicting principles were being applied by them in the administrative, social, educational and legal fields, and nowhere was there any survey of what was taking place in Africa as a whole." ${ }^{7}$ With this as his modus operandi, Hailey set off on a year-long fact-finding mission of Africa.

Hailey himself was not unaware of the importance of his mission and, just prior to his departure, observed with characteristic trenchancy that, "[h]istory will doubtless look back on this period as being the most critical stage of African development; errors that are made now for the lack of knowledge... may well create a situation which the future can rectify only at the cost of great effort and much human distress." ${ }^{\prime 8}$ In 1938, after traveling throughout Africa and compiling enough material to fill a 1,600-page volume, An African Survey was published. A remarkable synthesis of intellect and pragmatism, Lord Hailey's was a signally-important contribution to the evolution of the ideas and of the principles guiding the British mission in Africa. With it came a revolution in imperial ideology that, on paper at least, shifted the

\footnotetext{
${ }^{6}$ Pedler, "A Personal Appreciation," 346.

${ }^{7}$ Henderson, Newbold, 258 and Pedler, "A Personal Appreciation," 346.

${ }^{8}$ R. Coupland, "The Hailey Survey," Africa: Journal of the International African Institute 12, No. 1
} (1939): 3. http://www.jstor.org. 
objectives of the colonial administration from responsibility for law and order to a concern for the indigenous populations' social life and standards of living. ${ }^{9}$

What follows is a study of this shift, an examination that holds up a mirror to British notions about government through what was seen as a key principle of that change: social development. What must not be forgotten, however, is that this shift did not and could not occur in a vacuum overnight; there could be no flipping of switches here. Or could there? Knowing the results of the Survey, how could there be any revolution in the guiding principles of Empire without somehow reconciling metropolitan theory with colonial practice? Indeed, as Hodge has noted, the "disjuncture between metropolitan discourse and colonial practice" had, at its roots, "the structural constraints and material contradictions that punctuated the colonial project."10 Without bridging this gap, could a revolution ever truly be affected?

These not inconsiderable contradictions included most critically the inadequacies of colonial power in Africa; a power that had, over time, come to rely heavily on Africa's traditional patron-client social framework to put metropolitan theory into practice. When the rhetoric of Hailey's social development ideology hit the membrane of the reality of the British position in Africa, it was necessarily mutated, stripped of its vanity, and transformed into something resembling a revolution on its surface. In the end, this new, forward-looking paradigm of the imperial body politic looked very much indeed like a Lame Leviathan whose reach had exceeded its grasp.

To render this examination legible and relevant to the study of the Late Colonial, it is couched within an analysis of two development projects, one that came before the African Survey and one that came after. Accordingly, I have chosen to look at the two largest and most

\footnotetext{
${ }^{9}$ Lee, Colonial Development, 78.

${ }^{10}$ Hodge, Triumph, 12.
} 
ambitious development programs introduced by the British Colonial Government in the Sudan: the Gezira Scheme, which pre-dates the Survey, and the Zande Scheme, which came after. Aside from the more specific considerations mentioned above, an understanding of the contrasts and continuities between these two projects is important on two rather fundamental levels. Firstly, and practically-speaking, it is difficult to atomize imperial policy into the constituent precipitating events that gave rise to ideological divergences in Africa during the colonial period - the "shift" mentioned above - and, should that considerable task be accomplished, the theoretical understanding of such complex and mutually supporting variables is rather more daunting without an examination of how such relations and variables play themselves out on the ground as specific practices. Secondly, the historiography of the British Sudan is curiously absent a direct comparative study of these two undertakings - an eyebrow-raising oversight when it is considered that such an analysis would go a long way toward understanding not only the evolution of social development within the essentially fluid imperial schemata of the latecolonial period, but also help to contextualize events which would happen much later, such as the Sudanese Civil War.

Putting to one side these long-term implications, broadly-speaking Gezira and Zande are symbols of the investment of the Empire in the Sudan and, by the mere virtue of their existence, exemplify the two extremes in imperial development ideology. Gezira manifestly represents the imperial obsession with the creation of economically viable colonies - a product of the persistent corrosive effects of successive global economic woes and therefore an epiphenomenal product of stability-inducing "law and order" - while Zande epitomizes Hailey's emphasis on the social development of indigenous peoples. These pedigrees suggest the essential paradox at the core of my study: the overwhelming success of Gezira and the catastrophic failure of Zande - facts that 
point to the fundamental questions guiding my research. Firstly, how do we explain Gezira's longevity? Driven from the outset by economic considerations, over time it became not only the backbone of the Sudanese economy, but also something more: a model of social development. Moreover, how is it that Zande, intended exclusively to be a mechanism for the social development of the Azande people, devolved into a scheme shorn of its nobler intentions; one driven primarily by economic considerations? Answering these questions not only hints at the meta-narrative - that is, the revolution in mid-twentieth century imperial ideology - but also problematizes some of the logic underlying key aspects of social development imperialism. 


\section{Chapter Two: \\ The Law and Order Empire}

Viewed through the lens of imperial ideology, the Gezira and Zande Schemes can be seen as either negative or positive, carving out a sort of ideological archipelago defined by the undulations of the current of metropolitan theory - as gradually translated and, of course, transformed - into colonial praxis. Over time, these islands changed their orientation, shifting with the needs - real, imagined, or even imposed - of the Government. Thus writ large, the landscape of the Sudan was, in effect, a map of imperial policy - a great plan that tells the rich story of the Empire itself, from its halcyon days at the dawn of the twentieth century to the realization of its own self-liquidation some sixty years later.

Rather more to the point, the story of the Gezira Scheme is bound up with the history of the Anglo-Egyptian Condominium, particularly the strategic requirements that galvanized the partnership between the British and Egyptian codomini. For the financial considerations obliged by the existence of the Suez Canal - the vital artery to the British Raj - did much to entrench the British in the khedivate's affairs. Indeed, access to wealth adds to any such relationship a certain patina of necessity, lubricating the machinery of the partnership with vast sums of money to keep it in working order. One does not need a particularly acrobatic imagination to recognize that a threat to the safety and stability of Egypt could endanger the realm. And, for a time, this very real threat fostered an atmosphere of cooperation between the two powers.

The foregoing is, perhaps, somewhat of an oversimplification. At least in London, the results of a quick cost-benefits analysis no doubt revealed a solution decidedly in favor of a heavy British presence along the Nile. But such a calculus gets us no further along in understanding the threats against British interests in Egypt - or, for that matter, how this led to development in the Sudan. For how could the Sudan, backward, underdeveloped, and de-linked 
from the rapidly globalizing economy, pose any danger to the grand imperial design? The answer can be found in the debris of the battlefield at Omdurman, where in 1898 the AngloEgyptian Military, under the command of the sirdar Lord Kitchener, decisively defeated the main force of the Mahdiyya. ${ }^{11}$ This movement requires some comment. After displacing their Ottoman overlords in 1880, the Mahdiyya - an indigenous Muslim protest movement that chafed under the yoke of foreign domination, be it Turco-Egyptian rulers or Christian overlords - forged an Islamic state in pre-colonial Sudan. The next two decades proved an austere period for the Sudanese. Plagued by famine exacerbated by decreased productivity linked to the service requirements of the Mahdist Khalifa, those landowners and cultivators who did not perish either produced merely enough food to meet their minimum needs or simply fled the Sudan entirely. ${ }^{12}$

In time, the Sudan grew increasingly isolated from world markets, retrograding economically for good measure. Circumscribed to a point where it existed on a subsistence economy with only a little gum, ivory, ostrich feathers, and hides and skins to be offered to external markets, the institution of the state - such as it was - devolved into little more than a tribalized hegemony, the defining characteristic of which was clannishness. In and of itself this posed little threat to the Egyptians or the British, but when it was considered that the Mahdist state could fall under the predatory influence of competing European capitalist states, like that of France or Belgium, the circumstance became decidedly more volatile. For, occupying the headwaters of the Nile River, the Mahdiyya of the Sudan, if properly stimulated, could threaten the fertile Nile Valley by damming the White or Blue Nile Rivers far to the south - quite possibly out of the effective reach of a military expedition. This, of course, heightened British

\footnotetext{
${ }^{11}$ Muddathir 'Abdel Rahim, Imperialism and Nationalism in the Sudan: A study in constitutional and political development, 1899 - 1956 (Khartoum: University Press, 1986), 39. As sirdar, Kitchener was the commander-in-chief of the Egyptian Army.

${ }_{12}$ Arthur Gaitskell, Gezira: A Story of Development in the Sudan (London: Faber and Faber Limited, 1954), 32.
} 
desire to reestablish control of the Sudan and led rather directly to Kitchener's two-year campaign which culminated in the defeat of the Mahdists at Omdurman.

In short order, the British leveraged this and their military superiority to establish AngloEgyptian Condominium rule over the Sudan - a decidedly questionable arrangement, since at the time Egypt and the Sudan were both vassal states of the Ottoman sultan. The relative weakness of the Ottoman Empire, however, can only have alloyed the sultan's claims in the eyes of the British, whose strategic considerations regarding the Suez Canal far outweighed the tactful niceties of respecting the increasingly porous boundaries of the Sick Man of Europe particularly when confronted by the juggernaut of British imperialism. Notwithstanding this, colonizing the Sudan was not without difficulties for the Leviathan for, though the main body of the Mahdiyya had been decimated at Omdurman, pockets of resistance persisted for some decades.

This resistance obliged the British to engage in a prolonged, resource-draining operation to pacify the countryside - especially in the South, the vast geographical extent of which vitiated the superiority of British technology and reduced the effectiveness of imperial resources. ${ }^{13}$ The resultant "mopping up" resonates with contemporary events in Southern Rhodesia and Buganda where, in the first instance, the British South Africa Company engaged in a series of wars against the Ndebele state and, in the second, the British East Africa Company confronted the hard-line intransigence of the brasura, the Kingdom of Bunyoro's special standing army of trained men organized under the monarch Mukama Kabarega. ${ }^{14}$ It would take the imperialists nearly a

\footnotetext{
${ }^{13}$ Robert O. Collins, Shadows in the Grass: Britain in the Southern Sudan, 1918 - 1956 (New Haven: Yale University Press, 1983), 33.

${ }^{14}$ Terence Ranger's book, Revolt in Southern Rhodesia, 1896-97, is arguably the best examination of the Ndebele Wars, though Ranger's assertions regarding the relative importance of religion and magic in the organization of indigenous resistance against the British have been largely disproved. For an excellent study on the Kingdoms of Buganda, see Edward I. Steinhart's Conflict and Collaboration: The Kingdoms of Western Uganda,
} 
decade to bring these insurgent elements to heel and, at least in the Sudan, cause enough grief to justify governing under martial law - arguably the epitome of the law and order empire - until 1926, the Gezira Scheme's first full year of operation. ${ }^{15}$

That same year was to prove a fiscal watershed in Khartoum, where the Government of the Sudan reported $£ E 5.2 \mathrm{M}$ in revenue, a cool three-quarters of a million of which were attributed to receipts from Gezira alone. Barely a quarter of a century before, the Condominium reported a paltry revenue of $£ \mathrm{E} 35,000$ for the whole of the Sudan. ${ }^{16}$ This rather dramatic shift begs the question, what changed? The answer can be found in the contours of the maturation of the Condominium as the British mission in the Sudan evolved. To contextualize this, the institution of the Condominium must first be situated within the rubric of contemporary imperial ideology and its chief guiding principle, colonial self-sufficiency. The nucleus of this ideology dates back to 1852 and the administration of Lord John Russell, who tasked the newly-minted Colonial Secretary Earl Grey to undertake a grand review of the British Colonies. Begun in 1846, the survey took six years to complete, at the end of which Grey promulgated the metropole's official view of empire: “...the surest test of the soundness of measures for the improvement of an uncivilized people, is that they should be self-supporting; and great advantage arises from throwing those who are to carry plans of this kind into effect upon their own resources. The people also, for whose benefit such measures are attempted, are rendered more sensible of their value when the pecuniary means required for their adoption are furnished by themselves." 17 With those two sentences, Grey unapologetically caulked over the cracks in

1890 - 1907. Steinhart's book is similar to Ranger's in that it examines indigenous collaboration and resistance within the context of penetration and settlement by a British Charter Company.

${ }^{15}$ Collins, Shadows, $41-43$.

${ }^{16}$ Gaitskell, Gezira, 32.

${ }^{17}$ Earl Henry Grey, The Colonial Policy of Lord John Russell's Administration, Vol. II (London: Richard Bentley, 1853 ), 281. 
the foundation of empire on the cheap by invoking its great ideological Moloch: the civilizing mission. It was to have a lasting effect on the evolution of the Empire and would not be displaced until the 1920s, with the promulgation of Lord Lugard's Dual Mandate.

In the meantime, at the juncture of Grey's conceit, the threat of competing capitalisms in the form of France and Belgium, and the strategic considerations obliged by the Suez Canal, lay the Anglo-Egyptian Sudan, relentlessly vast and virtually untouched by the Machine Age. Here, in December 1899, Sir Reginald Wingate assumed the governor-generalship, helming the administration during its austere, formative years. It is over the course of Wingate's tenure in Khartoum and, still later, Cairo that the notion of a grand irrigation scheme at the confluence of the Blue and White Nile Rivers - the Gezira Plain - incubated and received much crucial impetus. In fact, less than a year into his governor-generalship, Wingate was already musing about the potential for irrigation at Gezira. Indeed, in 1900, he wrote, "As there is only one crop grown during the short rainy season, and as this cereal is planted and harvested within a period of sixty to eighty days, it follows that if a system of irrigation were feasible in the Gezireh, it would become a huge granary capable of supplying not only the whole Soudan but other countries as well." ${ }^{18}$ Arguably, the introduction of cotton cultivation fitted very conveniently into the governing ideologies of both Grey and, as we shall see, Lugard, as a crop that benefited both the cultivator and the metropolis. ${ }^{19}$ But rather more than this and quite pragmatically-speaking, it benefited to a considerable degree from the construction of railways - which itself proved a boon to the metropolitan steel industry in a period when the construction of the American and European railway systems had been largely completed.

\footnotetext{
${ }^{18}$ Gaitskell, Gezira, 36.

${ }^{19}$ Ibid., 48.
} 
In these and many other respects, Wingate echoed and, in effect, continued the theme of planned purpose in development outlined by Viscount Cromer, British Consul-General in Egypt. ${ }^{20}$ Writing to the Foreign Office in 1900, Cromer observed, "The Soudan is in a far more backward condition than was the case with Egypt when work of reform was taken seriously in hand. The work of introducing civilization into the Soudan may not improbably present somewhat similar features. Time is above all things required. The main condition of ultimate success is, I venture to think, that whatever measures taken should be deliberate, and that the work of reform should not be hurried. [...] The two most pressing needs...are, I think, first an increase in the number of British officials and secondly, the expenditure of capital on railways and irrigation." ${ }^{21}$ A consummate colonialist and skillful bureaucrat, Cromer was no doubt aware that, in framing the Sudan as he had, his letter spoke directly to the purposefulness and applicability of the Imperial Estates Doctrine. As designed by Joseph Chamberlain, the Secretary of State for the Colonies, the Doctrine was intended to maximize the efficiency of Britain's vast colonial possessions in order to revive its ailing economy - suffering, as it was, from the combined effects of the late nineteenth-century depression and growing international competition. The idea was that a program of state-directed "constructive' imperialism" - which

\footnotetext{
${ }^{20}$ Sir Evelyn Baring, Lord Cromer, British High Commissioner in Egypt and the architect of British policy in the Sudan. It was Cromer who negotiated the Anglo-Egyptian Condominium Agreement in 1899, wherein Egypt and the Sudan were to be administered as one country. When discussing the creation of aforesaid Agreement, Cromer noted, 'It was necessary to invent some method by which the new Sudan should be, at one and the same time, Egyptian to such an extent as to satisfy equitable and political exigencies, and yet sufficiently British to prevent the administration of the country being hampered by the political burr which necessarily hung on to the skirts of Egyptian political existence.' See in Sir Harold MacMichael, The Sudan (New York: Frederick A. Praeger, 1955), 65 and M.W. Daly, The Sirdar: Sir Reginald Wingate and the British Empire in the Middle East (Philadelphia: American Philosophical Society, 1997), 134.

${ }^{21}$ Gaitskell, Gezira, 33. Here, it is worth commenting on the distinctions between Foreign Office oversight and that of the Colonial Office insofar as the Sudan was concerned. To quote Daly, "The early administration [of the Sudan] combined aspects of Turco-Egyptian government with elements of Egyptian army bureaucracy. [...] In this and other respects the Sudan Government differed from British colonial regimes elsewhere. Condominium, in Wingate's day, meant that sovereignty was shared by Britain and Egypt, no matter how unequally they exercised it. The Sudan's affairs were overseen in London not at the Colonial Office but by the Foreign Office, where Cromer's Condominium was merely a diplomatic device and the Sudan a barbarian land needing occupation to ensure Egypt's security." See in Daly, The Sirdar, 141.
} 
called upon the Government to provide the necessary financial and technical assistance for the extension of imperial communications in cases where it would mobilize its unexplored wealth in tropical Africa and the East. This had the effect of creating new markets abroad for British industrial goods and services, such as railways, while reversing the trend of unemployment at home. The revenue this generated would, in turn, lubricate the engine of the British economy while stimulating and perpetuating the machinery of the Empire overseas. ${ }^{22}$ Constructive imperialism would serve as the device that defined the relationship between the metropole and her colonies until after the Great Depression.

Notwithstanding this, Cromer's correspondence to the Foreign Office was more than simply an endorsement for metropolitan colonial theory. Rather, his sentiments spoke to the reality of the situation on the ground, of both the Sudan's financial condition and the need to ensure law and order. One should exercise caution, however, in assuming that this was anything approaching a formal principle to the administration of the Sudan. Indeed, it must be understood that while it was treated as an appanage of Egypt, the British did not administer the whole of the Sudan as a single entity. It was, in fact, keenly divided between its Arab North and Black African South - a bifurcation that pre-dated the reconquest. The logistical rationale underlying the perpetuation of this administrative legerdemain stems from, as implied above, the infeasibility of communicating with the South effectively - due to its remoteness, vastness, and lack of infrastructure. Furthermore, the most heavily tribalized regions of the Sudan were found there, thus it was also the least secure and most dangerous. This fact alone necessitated a series of punitive military expeditions into the region designed to pacify the countryside and compel a

\footnotetext{
${ }^{22}$ Hodge, Triumph, 22.
} 
rudimentary framework upon which government-imposed stability could be grafted. ${ }^{23}$ Given this, what evolved rather quickly was a separate, exclusive approach toward the southern region which, over time, came to be called the Southern Policy. It has been argued that what amounted to a specific policy toward the Southern Sudan passed through two distinct phases, a notion that implies a high degree of organization not just to the administration of the South, but also to its insulation throughout the period of British sovereignty. Quite simply put, however, a purposefully directed strategy could not be a priority until pacification had ended and reconstruction was underway. So considered, the Condominium's nascent southern policy was at best a byproduct of the exigencies of reconquest and rule; not a forward-looking, development-minded blueprint for the future of the region - a fact that would have grievous unintended consequences.

Significantly, then, for nearly four and a half decades the South was all but excluded from the modernizing impetus that gradually transformed the North. The South would have a separate story of development that, though irrevocably linked with the North, followed a divergent path, one charted by Lord Hailey's social development ideology and epitomized by the Zande Scheme. But these events and the fulfillment of the grand self-liquidating design of decolonization were still decades away. To rationalize them, we must first understand their genesis in the Sudan of the Wingate Era.

Ever the proverbial burr in the imperial saddle, the chief problem confronting Wingate's administration of the Sudan was funding. A territory of a million square miles, the Sudan rippled with hundreds of miles of rolling sand dunes; a landscape scorched by a profundity of heat and parched by a dearth of water, wracked by sometimes continuous habubs (dust storms) -

${ }^{23}$ M.W. Daly, The Sirdar: Sir Reginald Wingate and the British Empire in the Middle East (Philadelphia: American Philosophical Society, 1997), 151. 
conditions that led Cromer to lament, "I should add that I see little immediate prospect of unaided private capital, on any considerable scale, seeking for investment in the Soudan." ${ }^{24}$ Yet decades earlier, Earl Grey had thrown down the gauntlet of colonial self-sufficiency, leaving it for pioneering governor-generals and their creative administrators to pick it up - if they dared. Emphasizing this, Grey wrote in 1852 that, "It does not appear to me that the people of [Britain], ought to be called upon to pay for the cost of extensive schemes of internal improvement in Africa. [...] Parliament is, I think, right to be very sparing in its grants for purposes of this kind $\ldots ., 25$

Given this, Wingate found himself in a rather unenviable position. The Sudan had virtually no mineral wealth and possessed few resources in the way of trade or produce that could have been taxed in order to raise revenue. Making matters worse, the recent experience of the Turco-Egyptian administration made it politically inadvisable to attempt to finance the government wholly from taxes. The painful irony in all of this was that, even if an irrigation project could get off the ground, there wasn't any money to build the dams and barrages necessary to conserve and manage the distribution of water. Hamstrung by these intractable conditions, Wingate deployed the only weapon in his funding arsenal: the lingering threat of resurgent Mahdism. The argument ran something like this: since the Sudan was an Egyptian possession, it was only fair that the cost of its administration be borne by the Egyptian Treasury. ${ }^{26}$ After all, had it not been for the reconquest, Egypt would have had to pay for the maintenance of a large and permanent force to guard her southern frontier against Mahdist invasion. $^{27}$

\footnotetext{
${ }^{24}$ Henderson, Newbold, 17 and Gaitskell, Gezira, 33.

${ }^{25}$ Grey, Colonial Policy, 122.

${ }^{26}$ Daly, The Sirdar, 151.

27 'Abdel Rahim, Imperialism and Nationalism, 54.
} 
Implicit in all of this, and an essential component underlying the Anglo-Egyptian Condominium, was the notion that Egypt and the Sudan were nominally one country - a sentiment promulgated by Cromer, infamous despiser of the "paraphernalia of internationalism." ${ }^{28}$ The outstanding feature of this arrangement was the composition of Wingate's heavily militarized government at Khartoum - a quintessential facet of the law and order empire. Alongside officers seconded from the British Army, there stood a cadre of Western-educated Egyptians helping to administer the Sudan. These administrative niceties aside, Wingate's plan worked. Between 1899 and 1912, Egypt either granted or made direct advances to Khartoum totaling some $£ \mathrm{E} 7.2 \mathrm{M}$, a subvention that afforded the Sudan enough financial stability to gradually build up confidence and administrative equilibrium. ${ }^{29}$ Extorting the Egyptian Government was, of course, anything but a long-term solution to the problems facing the Sudan. The real solution came about in the form of pressure from the British Cotton Growing Association (B.C.G.A.). In 1906, following the exploration of the future irrigation possibilities of the Nile system by William Garstin, a British irrigation engineer from the Egyptian service, and the completion of the Nile-Red Sea railway link, the B.C.G.A. approached the Condominium Government with a view to introducing commercial growing in the Sudan. ${ }^{30}$ This approach was rejected and pressure from the Association lapsed for three years. In the interim, Wingate was heavily criticized for stiff-arming private interests, "since, owing to the demand for cotton and the construction of the Nile-Red Sea railway, the eyes of capitalists and agriculturalists have been turned to the large areas available for cultivation in the Sudan." ${ }^{31}$

28 'Abdel Rahim, Imperialism and Nationalism, 51.

${ }^{29}$ Gaitskell, Gezira, 35.

${ }^{30}$ Ibid., 37. In 1904, Sir William Garstin published the first overall plan for the control of the Nile Basin. As proposed by Garstin, the Scheme would not need water in the dry months. He did propose, however, the construction of a dam or barrage at Sennar on the Blue Nile to provide irrigation for part of the Gezira. Thus, it was Garstin's work that laid the foundation for the construction of the fulcrum of the Gezira Scheme.

${ }^{31}$ Gaitskell, Gezira, 45. 
There being no Sudanese capital for investment, it was apparent that the best chance for significant agricultural and economic advance lay in foreign concessions - a notion that assumed a cornucopia of available land where situated concessions would not conflict with local interests. There was, however, a problem in all of this: pending the published results of the surveys conducted by the land commissions formed by the Titles to Land Ordinance (1899), no assertions could be made regarding land entitlement with a satisfactory degree of certainty. To wit, the Director of Agriculture, C.E. Dupuis, wrote impatiently in 1904, "In most places where land was applied for [by the foreign concession companies], the rights of the natives had not been enquired into and settled, no cadastral survey had determined the areas, and no Irrigation Department had been formed to take levels and to devise schemes for irrigating the land, nor," and here the Director hit upon a crucial concern, "was it known how much water for summer irrigation Egypt would allow the Sudan to utilize for its own purposes.",32

Notwithstanding this, pressure increased on the Sudan Government and in the Trade Section of his Report of 1910, causing Wingate to respond to the growing criticism that Khartoum had been "dilatory and unsympathetic towards schemes of experimentation." "I3 wish to point out," he explained, "that the disappointments of earlier days were almost entirely due to lack of recognition that the Sudan Government had no right to look beyond the first duty of providing Egypt with a firm buttress on her southern frontier at as little cost as possible." In the same paragraph, however, Wingate acknowledged that circumstances in the heart of England's textile industry had changed, making further vacillation by Khartoum - no matter how well-intentioned - anathema to London. "A new situation has arisen," the governor-general wrote. "It may be summed up by saying that a policy of mere pacification has to be expanded

\footnotetext{
${ }^{32}$ Gaitskell, Gezira, 45. Emphasis mine.

${ }^{33}$ Ibid., 50.
} 
into one which recognises as an end the creation of a community on an independent economic basis.... An encouraging agricultural feature is the large increase in rain-grown cotton from the Gezira." 34

Wingate's "new situation" was, in actuality, a euphemism. What it referred to was the aggregation of anxiety in Lancashire, Britain's textile hub, concerning global cotton supplies. The B.C.G.A.'s approach to the Sudan Government in 1906 can be said to be symptomatic of this anxiousness, which was soon to be exacerbated by the failure of both the Egyptian and the American cotton crops. Whereas Lancashire held, in the past, a virtual monopoly on textile manufacturing, in the latter decades of the nineteenth century its position grew increasingly threatened by competition from the United States, Germany, and even China. Gradually, this competition pushed Lancashire's interest toward the finer end of the market, and in the process into greater dependence on the fine long-staple cotton produced in Egypt. In Egypt itself, the oppression of the fellah was so great and the collection of taxes so vicious, that people were fleeing the land, causing a precipitous drop in cotton production. ${ }^{35}$ This made the position of the Lancashire cotton industry, which had grown increasingly inflexible due to its dependence on long-staple cotton, that much more precarious. As its demands for fine cotton increased, so the yield correspondingly decreased.

There were, however, positive signs that hinted at the productive capacity of the Sudan. Cotton yields at Zeidab ${ }^{36}$, the only large-scale foreign concession granted by Khartoum and managed by the Sudan Experimental Plantations Syndicate ${ }^{37}$, were greater than had been 1911), 14.

${ }^{34}$ Reports on the Finances, Administration and Condition of the Sudan, 1910 (Cairo: F. Nimar \& Co.,

${ }^{35}$ Tony Barnett, The Gezira Scheme: An Illusion of Development (London: Frank Cass, 1977), 5.

${ }^{36}$ Located northeast of Khartoum along the Atbara River.

${ }^{37}$ The Sudan Plantations Syndicate, variously referred to throughout this document as "S.P.S." or simply the "Syndicate," was reorganized in 1907. It was formerly known as the Sudan Experimental Plantations Syndicate. 
anticipated. This undertaking requires some comment. To develop the concession, Leigh Hunt, a wealthy American businessman, set up the Sudan Experimental Plantations Syndicate in 1904, enlisting the cooperation of a number of London-based merchants. By 1907, only 1,600 feddans had been irrigated - out of the 10,000 awarded to Hunt and his Syndicate. ${ }^{38}$ These early years of the project proved anything but remunerative, but in time the Sudan Plantations Syndicate (S.P.S.) struck upon an alternative development method that jettisoned the cost-heavy usage of direct wage labor: a tenancy system whereby tenants grew their own crops at their own expense under the Syndicate's supervision and according to the Syndicate's planned rotation, and paying a rental for the Syndicate's water. At the same time, the S.P.S. erected a ginnery and undertook to buy the cotton and other cash crops for marketing in bulk. In 1907, there were 25 tenants and, by 1908 , there were 102 - a sure sign of its improving circumstances. Crucially, the Sudanese themselves had begun applying to work on the project, a level of interest that indicated its ability to generate revenue. ${ }^{39}$

The productive and remunerative capacity of Zeidab proved to be the lightning rod for the vice-president of the B.C.G.A., Sir William Mather. As a governor and generous benefactor of Gordon College at Khartoum, Mather already had many connections with the Sudan. While these connections put him in close contact with events in Zeidab, his work in Lancashire put him at the center of the growing anxiety over the cotton supply. This intersection of interests put the machinery in place to link Hunt's Sudan Plantations Syndicate with the hand-wringing industrialists in Lancashire. Encouraged by Zeidab, which Mather considered the perfect "object lesson" for development of the Sudan wherever cotton might be cultivated, the B.C.G.A.

\footnotetext{
${ }^{38}$ One feddan is roughly equivalent to one acre.

${ }^{39}$ Gaitskell, Gezira, $52-54$.
} 
renewed its campaign, this time with a view to staving off what appeared to be an impending crisis in the industry. ${ }^{40}$

By 1913, Parliamentary M.P.s from Lancashire had become increasingly vocal about the plight of the cotton industry. Concerning the potential of Gezira, M.P. Bonar Law, elected by a Lancashire constituency and soon to be Colonial Secretary, said that “...if this experiment succeeds it is of direct advantage to the United Kingdom itself, for certainly, in my opinion, the great cotton industry, the greatest cotton industry in this country, can never be in the position which we should like to see it so long as it is dependent entirely, or almost entirely, for its supplies of raw material on foreign countries." ${ }^{41}$ In the background and away from all the noise coming from - or at least inspired by - the B.C.G.A., Prime Minister Asquith shuttled between Lancashire and Balmoral while Wingate shuttled between Khartoum and Balmoral, where hurried discussions were held with Lloyd George, Chancellor of the Exchequer, to secure a funding guarantee for an irrigation scheme along the Gezira Plain- a notion that was anathema to Grey and Russell just fifty years before. ${ }^{42}$

The affair came to a head in 1913 with a Parliamentary debate, during which the interests at stake were clearly laid out:

Experiments have abundantly proved that the Sudan is not only the finest cotton growing country in the whole of the British Empire, but, what is more important, that it can grow that sort of cotton Lancashire requires. This is a subject of vital importance to the textile north, and it is essential that the millions engaged in and dependent on the cotton industry should no longer be at the mercy of bad seasons in India or North America. If the shortage of raw material is to be prevented Lancashire must be placed above the hazards of speculation and climate. This loan will develop the resources of the Sudan under

\footnotetext{
${ }^{40}$ Gaitskell, Gezira, 55.

${ }^{41}$ Barnett, Gezira Scheme, 5.

${ }^{42}$ Sir Ronald Wingate, Wingate of the Sudan: The Life and Times of General Sir Reginald Wingate, Maker of the Anglo-Egyptian Sudan (London: John Murray, 1955), 156 and Gaitskell, Gezira, 57.
} 
British guidance in a way which will ensure the more permanent prosperity of the cotton industry. $^{43}$

It must have been difficult to hear oneself think over the din of all the patriotic chestthumping inspired by the plight of the cotton industry. In the event, it seemed rather remote that the B.C.G.A.'s interests would not carry the day and, indeed, by debate's end, Parliament had done something decidedly un-British: it enabled a loan in the amount of $£ 3 \mathrm{M}$ to be given to the Sudan Government to finance the capital work for irrigating part of the Gezira Plain between the Blue and White Nile Rivers. At this point, it is keen to imagine another sound mingling with the crescendo of the victory of private capital interests over the Empire of Self-Sufficiency, that of the Earl Grey spinning in his grave.

The vote to fund construction of the Gezira Scheme represents a convergence of both private interests and strategic metropolitan needs. On the one hand, Gezira, it was hoped, would insulate the British cotton industry from shortages on the finer-end of market while, on the other, it was believed that it would, in time, provide a much-needed source of revenue for the Sudan, itself occupied ostensibly to protect British interests in the Suez Canal. Furthermore, by proving that it could manage experimental cotton farming in the Sudan (first at Zeidab and then later and, most crucially, at Tayiba), Hunt's Sudan Plantations Syndicate was poised to manage the technical and administrative aspects of the Gezira Scheme, an arrangement that relieved Khartoum of a costly and burdensome obligation it was ill-equipped to handle. As is so often the case, however, things were not quite as straightforward as they seemed, for the British had learned valuable lessons in Africa, particularly in their dealings with Charter Companies. Once entrenched, as in Rhodesia, private enterprises like Rhodes' colossus, the British South Africa Company, could and did trammel all over government policy and native rights in their pursuit of

\footnotetext{
${ }^{43}$ Parliamentary Debate (Commons), $5^{\text {th }}$ Ser., 50 (1913): 17.
} 
riches. Necessarily then, both Wingate and Kitchener, now British Consul-General in Egypt, sought to devise strategies that would circumscribe the role of the S.P.S. The sticking point, however, was that without the S.P.S., the Sudan Loan would not have been enacted by Parliament. To wit, Wingate wrote to Major Lee Stack, the Sudan Agent in Cairo, "It is quite true that had the Government refused to come to our aid, it would have been better to have resorted to the help of a Company rather than not develop the Gezira at all, but in that case the Sudan would have eventually become something like Rhodesia is today, namely the Company would have acquired such power as would probably have resulted in its eventually being given a Charter." ${ }^{44}$ In the event, Kitchener took the lead in defining the terms of the partnership between the Sudan Government and the S.P.S. and, after much bargaining, agreement was reached, creating a kind of public-private collaboration.

These developments are emblematic of several fundamental changes in the imperial design, most especially ideologically and, of course, economically. We find implicit in the funding of the Gezira Scheme acknowledgement that the guiding principle of the British colonial endeavor - that of Earl Grey - had become outmoded. Though the concept of self-sufficiency would remain nominally a part of the administration of British Tropical Africa, it would be folded into the new ethos promulgated by Lord Lugard - his Dual Mandate - to work in concert with the laisser-faire approach engendered by the economics of free trade. That is, in time markets that had drifted and caused prices to fluctuate would, by their very nature, correct themselves without the intervention of the Government - it was Adam Smith resurrected, dusted off, and put on display in the shop windows of Empire.

All of this, however, was yet to come, for in 1914 events in Europe overtook the British, necessarily pre-empting work on the Gezira Scheme. The summer of that year, Austria crossed

${ }^{44}$ Gaitskell, Gezira, $65-66$. 
the frontier into Serbia, initiating the first great conflict of the Machine Age. The advent of World War I and its encouragement of Egyptian nationalism did much to undermine the foundations of the Anglo-Egyptian Condominium and, by War's end, had not only irrevocably altered the partnership, but also laid the groundwork for virulent Sudanese nationalism.

The First World War marked a crucial pivot on the axis of the administration of the British Sudan for, as the conflict consumed money and manpower, Khartoum re-evaluated its financial commitments. Not only was work on resource-draining operations such as Gezira halted - a "breathing space" during which the S.P.S. and the Government accumulated experience at its Tayiba and Barakat pilot stations - but the need to save money created conditions that were unintentionally protonationalist in their implications. ${ }^{45}$ Indeed, the calculus of the cost-benefits equation came down heavily in the Sudan, prompting the government to replace its Egyptian administrators - who could and often did demand up to 150 percent of the salary they would have earned at home - with Northern Sudanese. ${ }^{46}$ The long-term corollary of this was the subtle Sudanization of the administration, a change that created an ideal political and social atmosphere to pressurize the government to reform itself and, in time, create a sort of Sudan for the Sudanese. ${ }^{47}$

In the meantime, Wingate was promoted from Khartoum to the High Commissioner's Residency in Cairo. ${ }^{48}$ A man of what Lord Cromer considered "local experience," which in theory made the governor-general the ideal candidate for the job, Wingate's brief tenure as High

\footnotetext{
${ }^{45}$ Gaitskell, Gezira, 74. Gaitskell argues reasonably that, "This pause in operations at Gezira enabled details to be much more effectively thought out and led to important changes in the irrigation and agricultural designs. It influenced decisions on the critical question of how the Government was to acquire control of the land and who were to be the tenants. It gave time for attitudes to grow, most notably in two respects: the confidence between the Government and the Syndicate as partners and the confidence of the local people in the irrigation scheme."

46 'Abdel Rahim, Imperialism and Nationalism, 75.

${ }^{47}$ Ibid., 102.

48 Ibid.
} 
Commissioner was dogged first by the Arab Revolt and then by the Egyptian Revolution - more than any other, the event that triggered the dissolution of the Anglo-Egyptian Condominium. ${ }^{49}$ In the days after the signing of the armistice that brought an end to the First World War in November 1918, Wingate sent a dire message to the Foreign Office, warning from Cairo that there were "indications of a campaign directed against the Protectorate." ${ }^{, 50}$ The diabolical campaign to which Wingate referred lay at the confluence of a series of events largely beyond the control of the British: both the First World War and the Arab Revolt of 1916 stimulated the younger generation which had been through government schools and had acquired some idea of modern methods of administration by working in government offices. To an alreadycombustible situation was added perhaps the greatest accelerant, President Woodrow Wilson's Fourteen Points speech, which in many ways emphasized the imperial poison pills of national self-determination and sovereignty. ${ }^{51}$

As these conditions drew the nationalists together, years of wartime requisitioning and hardships made worse by broken promises of independence exacerbated their growing frustration. In Cairo, protests against British occupation signaled manifestly that the clock could not be turned back to 1914 - there would be no return to the untroubled days of the Condominium. ${ }^{52}$ During the winter of $1918 / 19$, low-intensity violence continued throughout Egypt until, in March, the British military arrested and deported four of the movement's leaders. ${ }^{53}$ Acting High Commissioner Sir Milne Cheetham, not convinced that the deportations

${ }^{49}$ Daly, The Sirdar, 134.

${ }^{50}$ Ibid., 281-282.

51 'Abdel Rahim, Imperialism and Nationalism, 89.

52 John D. McIntyre, The Boycott of the Milner Commission: A Study in Egyptian Nationalism (New York: Peter Lang Publishing, 1985), 17.

${ }^{53}$ Ibid., 26. 
would check the nationalist movement, predicted that the initial result would be one of "irritation and sympathy with the deported ringleaders." ${ }^{54}$

Less than ten days later, he was proved right as open revolt consumed the provinces of Behera, Gharbia, Munufia, and Daghalia. ${ }^{55}$ Nearly all of the railway stations were burned, many of the agricultural roads had been destroyed, and, throughout Egypt, Europeans were being attacked. ${ }^{56}$ It took the intervention of General Bulfin, the Acting Commander-in-Chief of the Egyptian Expeditionary Force, and his threat to quell the uprising with active suppression, to restore order. ${ }^{57}$ In spite of the ostensible peace that existed by the time the Special High Commissioner to Egypt General Lord Edmund Allenby arrived to replace Wingate, who was by then the unofficial scapegoat for the failure of British policy in Egypt, resentment had fused with nationalist sentiment to create a decidedly dangerous situation on the ground.

These events, and the increased danger to British interests by the spreading of the spirit of nationalism into the Sudan - where the majority of the population were, by virtue of their common language, religion, and recent experience, generally inclined to sympathize with the Egyptians - induced the British Government to revise, and indeed to reverse, its former policy with regard to the relationship between Egypt and the Sudan. As soon as was practically feasible, the British uncoupled the Sudan from Egypt - politically, economically, and culturally. The reasons for this sweeping change - for it was a dramatic shift away from the policy promulgated in 1899 by Lord Cromer, which held that the Sudan was a province of Egypt - were clearly set out in a letter Wingate sent to Lord Hardinge, the Permanent Under-Secretary of the

\footnotetext{
${ }_{55}^{54}$ McIntyre, Boycott, 26.

${ }^{55}$ Ibid., 29.

${ }^{56}$ Ibid., 26.

${ }^{57}$ Ibid., 30.
} 
Foreign Office, in December 1918, three months prior to the outbreak of the revolt. ${ }^{58}$ Ironically, it is Wingate who, after his ignominious departure from Egypt in January 1919, set the tone of future development of British policy in the Sudan. Indeed, his arguments and conclusions were, in one form or another, echoed in subsequent statements of policy including Lord Milner's Report of 1920.

In his correspondence, Wingate emphasized "in the strongest possible manner, the importance - from a British Empire point of view - of keeping the Egyptian and Sudan question totally apart. ${ }^{, 59}$ He continued:

As long as we hold the Sudan we hold the key to Egypt because we control the source of its water supply. Therefore, whatever the eventual political fate of Egypt may be, I beg that the Sudan may be entirely excluded from its orbit. As it stands, the Sudan is of the greatest importance to us strategically - besides being a future asset to the Empire of no mean value. But as an apanage of Egypt (under a form of independence or even quasiindependence) it would be a positive danger to us - for it would at once become a hotbed of Egyptian and foreign intrigue and would draw into its sphere of disturbance the adjoining possessions of Central Africa, Abyssinia, Eritrea, etc. [...] I would even suggest that should a favorable opportunity occur, its severance from Egypt could be rendered still more complete by obtaining the assent of the Powers at the Peace Conference to its definite acquisition by Great Britain. ${ }^{60}$

So it came to be that, by December 1919, when the Special Mission under the chairmanship of Lord Milner arrived in Egypt, agreement had already been reached by those who were on the spot that, whatever the Commission's recommendations with regard to Egypt, the question of the Sudan was to be treated separately. ${ }^{61}$ As for the manner in which this policy was to be implemented, it was confidentially reported to Milner that,

\footnotetext{
${ }^{58}$ Daly, Sirdar, 151 and 'Abdel Rahim, Imperialism and Nationalism, 59.

59 'Abdel Rahim, Imperialism and Nationalism, 52.

${ }^{60}$ Ibid.

${ }^{61}$ Ibid., 60.
} 
From a Sudan [Government] point of view, the ideal solution would be an immediate clear cut from Egypt. The Turkish Peace Treaty declare that all Turkish rights in Egypt and the Sudan (the Nile Basin) were ceded to Great Britain. Lord Milner's Report would recommend such measure of internal self government for Egypt as might be considered right, but would point out the absurdity of claims made by Egypt to Egyptian Nationalism for the Sudan, stating at the same time how the Sudan differs in race, tradition and sympathy from Egypt, and showing that Egypt's only legitimate interests in the Sudan are the safe-guarding of her water supply and the protection of her frontiers from external aggression. $^{62}$

The investigation of the Milner Commission concluded with two reports, that of A.W.

Keown-Boyd, an agent sent to the Sudan on behalf of the Commission, and that of the Special

Mission itself, the latter “anticipating Britain's unilateral declaration of Egyptian independence

in 1922."63 There was, of course, general agreement between the two reports that Egyptian influence had to be eliminated from the Sudan. ${ }^{64}$ In his "Report of the Special Mission to Egypt," Milner noted,

Having regard to its vast extent and the varied character of its inhabitants, the administration of its different parts should be left, as far as possible, in the hands of the native authorities, wherever they exist, under British supervision. A centralized bureaucracy is unsuitable for the Sudan. Decentralization and the employment, wherever possible, of native agencies for the simple administrative needs of the country, in its present stage of development, would make both for economy and efficiency. At the present time the officials of local origin are still largely outnumbered by those introduced from Egypt, with whom service in the Sudan is by no means popular. This difficulty will be overcome as education progresses and a greater number of Sudanese themselves become capable of filling official posts... There is no room in the Sudan for a host of petty officials, and education should be directed to giving the Sudanese a capacity and a taste of employment in other directions, such as industry, commerce, and engineering. The immediate need of the country is material development, and it can do without an elaborate administrative system. ${ }^{65}$

62 'Abdel Rahim, Imperialism and Nationalism, 60.

${ }^{63}$ Heather J. Sharkey, Living with Colonialism: Nationalism and Culture in the Anglo-Egyptian Sudan (Berkeley: University of California Press, 2003), 76.

${ }^{64}$ Collins, Shadows, 52.

${ }^{65}$ Ibid., 53. 
No one could fault Milner for being short-sighted, for his report also suggested that, in time, the Southern Sudan should be severed "from its Northern (Arab) area and...[linked] up with some central African system to be borne in mind" - a notion that was to gain traction throughout the 1920s and culminate in the Southern Policy of $1930 .{ }^{66}$ Most critically, however, the Commission recognized that unless the spread of nationalism was checked, it was increasingly likely that the Sudan would succumb to revolutionary ferment much like its Egyptian neighbor. All other concerns were subsumed in this, prompting the Commission to advise the Government to align its fundamental governing principles with those of Lord Lugard's Dual Mandate, the effectiveness of which Lugard had proved during his time as British High Commissioner in Nigeria. As designed, Lugard's policies stressed devolution at the level of local administration, eschewing the delineation of local authority along modern lines in favor of tribalized units that reported up through chieftains. As deployed, the principle of indirect rule served two mutually-supporting purposes: firstly, by grafting its own administrative imperatives onto the pre-existing tribal framework, it saved the Government money whilst ensuring the fulfillment of its own imperial agenda - with an acceptable (read, unavoidable) minimal loss of efficiency. Secondly, as this paradigm was fundamentally a perpetuation of the pre-colonial structure of government, it thwarted the mechanisms of modernization suspected of inciting the Egyptian Revolution. For anyone paying attention - or blessed with an overlong historical memory - Lugard's policies were strikingly familiar: similar mechanisms, shorn of their modern loading, were used by James I in 1609 to pacify the Hebridean Islands. ${ }^{67}$ One can see in

\footnotetext{
${ }^{66}$ Collins, Shadows, 53.

${ }^{67}$ The Statutes of Icolmkill were crucial in the forging of "Great Britain" and, by extension, the British Empire. In promulgating the Statutes, the English king James I (and VI of Scotland) effectively brought to an end the period of "Rough Wooing" that characterized the relationship between England and Scotland during the last half of the sixteenth century. Aimed specifically to counter the ongoing intransigence of the clans that called the Scottish Gaels their home, the Statutes of Icolmkill (1609) legislated, inter alia, to restore decayed religion, encourage hospitality, and discourage idleness, begging, drunkenness, and the keeping of firearms. For my discussion, the
} 
Lugard's Dual Mandate a sort of recapitulation of James's Statutes of Icolmkill, with all their trappings of devolution and decentralization - only dressed up and paraded around British Tropical Africa.

Clearly, at the leading edge of the development of the Gezira Scheme was a very specific set of circumstances that, in the aggregate, motivated the British to cultivate the vast triangular plain between the White and Blue Nile Rivers - albeit fitfully at first. Indeed, the loss of the Egyptian subvention in 1911, the outbreak of the First World War, the Arab Revolt of 1916, and the Egyptian Revolution of 1919 made for a make-or-break decade for the British in the Sudan, during which time the good ship Anglo-Egyptian Condominium ran aground on the great ideological sandbar that was Egyptian nationalism. The squall that caused the wreck having largely subsided, the British resumed work on the Gezira Scheme imbued with a new sense of purpose and vigor - impetus inspired by the completion of the Sennar Dam in 1925 and reflected optimistically in a speech made by Lord Lloyd, the High Commissioner for Egypt and the Sudan, on the day the dam was officially opened. "I desire finally," Lloyd concluded, "to touch upon another important consideration of a more general character. The ties between the Government and the people of the Sudan have always been those of personal friendship, and it is a first principle of the Gezira scheme, as it will be of any similar projects which may be undertaken in this country, that so desirable a relationship should be sedulously preserved." ${ }^{\circ 8}$ And nothing better illustrates the success of that persistence than the salutary remarks made by GovernorGeneral Stewart Symes as, some eight years later, the Sudan weathered the Depression: "The completion of the Sennar dam marked the beginning of a new era in the development of the

Statutes' relevance stems from the principles of devolution and decentralization they outlined. See in David Armitage, "Making the British Empire: Scotland and the Atlantic World 1542 - 1707," Past \& Present, No. 155 (1997): 34 - 63 and in Simon Schama, A History of Britain, Vol. II (New York: Hyperion, 2001), 32 - 33. ${ }^{68}$ Reports on the Finances, Administration and Condition of the Sudan in 1925, Cmd. 2742, at 6 
Sudan'; during the subsequent three years the revenue of the country increased by a fifth. Sir John [Maffey, Symes's predecessor in Khartoum] concentrated the extra money available on extending the Gezira scheme as a measure of insurance against low cotton prices; on an expansion of social services; on the pushing forward of bold experiments in native local government, and on the improvement of the country's communications..."69

Though events leading up to Lord Lloyd's remarks on January 21, 1926 obliged a level of fiscal austerity on Khartoum that made unnecessary infrastructural improvements anathema to the administration, prior to 1914 the British had made considerable advances toward settling the countryside. Though tangential at the time, these were, in the long-term, fundamental to the Scheme's success. The most crucial of these advances involved answering the question of land settlement, a process that must be considered within the framework of post-reconquest Sudan, if the end result is to be rationalized. The first objective of land policy following the reconquest was to get the local people back to work on the land. Along the Nile, 15 years of instability during the Mahdia had driven many landowners and cultivators away. Disease and warfare had further reduced their numbers. Although in the great nomad areas in the rain-lands where it was plentiful, land had been held in common by the tribe and distributed for individual usage by the chief, along the Nile, where cultivation was not a shifting uncertainty but involved fixed capitalassets like water-wheels and bullocks, land had come to carry with it firm individual rights. ${ }^{70}$ It could be sold, transmitted to heirs, rented and mortgaged for money or a share of the crops. ${ }^{71}$

The growing assurance of fair administration and reasonable taxation combined with the Government's need to bring the land under cultivation to produce a rather unintended consequence: it unleashed a wave of disputes over land rights. The absence of secure land titles

\footnotetext{
${ }^{69}$ Reports on the Finances, Administration and Condition of the Sudan in 1933, Cmd. 4668, at 1.

${ }^{70}$ Darfur, Eastern Sudan, Abyei, Southern Blue Nile, Malia, and Rizegat constitute the Sudanese rain-lands.

${ }^{71}$ Gaitskell, Gezira, 42.
} 
had the effect of forestalling any land cultivation, lest egregious errors be made in the dispensation of plots. To remedy an otherwise intractable set of circumstances, the British passed the Titles to Lands Ordinance - already mentioned in this discussion - establishing land settlement commissions whose mandate was the sorting out of the conflicting claims. As if this wasn't enough, the reconquest created an opening for intensive land speculation, much of it originating from Egypt where recent irrigation works raised the selling price of land - prompting land hunger elsewhere. These conditions provoked a second objective to the land policy: the control of the transfer of land so that, while the native cultivator was not sacrificed for the speculator, the genuine investor was not discouraged. ${ }^{72}$

The byproduct of these twin aims of protection and development was perhaps the first step in the long march toward social development in the Gezira: the creation of a peasant proprietary class. ${ }^{73}$ In time, it was argued, the land would suffice to keep the people in a reasonable state of prosperity and allow for a natural increase in the population. With this in mind, the Government promulgated the Gezira Land Ordinance of 1921. A further proclamation in 1923 augmented the ordinance and brought the transfer of land under still stricter control, making it impossible for a native landowner to dispose of his land without the consent of the Government. It also decreed that, for the present, no consent would be given to sales unless the land had already been registered. In the Gezira, this had the effect of keeping the land in the hands of the local cultivators. Thus, in 1924 - a year before the Sennar Dam was completed the Foreign Secretary was able to report to the British Parliament that, "The result of this policy has been that practically the whole of the land in the Gezira remains in native ownership divided into comparatively small holdings, so that it may be said that, not only has the foreign land

\footnotetext{
${ }^{72}$ Gaitskell, Gezira, 43.

${ }^{73}$ Ibid.
} 
speculator been kept out, but also the wealthy native absentee landlord, and the whole of the land remains in the ownership of the actual cultivators who work upon it."74

Land settlement was essential to the creation of a legible scheme based on tenant farming. ${ }^{75}$ As noted earlier, the S.P.S. had enjoyed considerable success with tenant farming at Zeidab, and would still later at Tayiba and Barakat. Evidence of the confidence this engendered can be found in the notification the Government sent to landowners ahead of publishing the Gezira Land Ordinance. One of the basic conceits made in the notification was that, as far as Gezira was concerned, "The general scheme adopted at Tayiba and Barakat would be followed."76 Fundamentally, then, the Ordinance carried forward the lessons learned through these pilot schemes - such as the mechanism of tenancies instead of the use of wage labor to guarantee cultivation. Most importantly, however, it established control over the land without outraging the traditional right of proprietorship while preventing the landowner from using that right to extract anything from the future tenant. That is, the right of ownership became only a right to a certain rental, a saleable security backed by loans guaranteed by the British Treasury. In this way, the land became quasi-nationalized.

From all of this gradually emerged a peasant proprietary class - it grew cotton on its Government-backed tenancies that was ginned by the S.P.S. to be sold on the market. The profits were shared between the partners - the tenant, the British Government, and the Syndicate. In turn, this arrangement gave the tenants advantages normally available only through large-scale estate management: loans at low interest rates, machinery, selected seed, fertilizer, processing, and marketing - all instruments of modern agriculture otherwise completely beyond the reach of

${ }^{74}$ Gaitskell, Gezira, 45.

${ }^{75}$ Christopher Bonneuil, "Development as Experiment: Science and State Building in Late Colonial and Postcolonial Africa, 1930 - 1970,” Osiris 15, No. 2, Nature and Empire: Science and Colonial Enterprise (2000): 264. http://www.jstor.org.

${ }^{76}$ Gaitskell, Gezira, 84. 
rural peasant farmers in Africa. This had the effect of creating a structure that raised the peasants' standard of living, an essential starting point for social development.

One must not assume, however, that this was the intent of the Gezira Scheme. From the outset, social development was simply not its goal. Rather, we find inherent in Gezira a multiplicity of causal factors unrelated to the advancement of the people: the global context, specifically the protection of the Suez Canal and the need to insulate Lancashire and, by extension, the British economy, from shortages on the fine-end of the cotton market; accentuated by international imperatives, particularly the need to protect the headwaters of the Nile to ensure the health and longevity of the Anglo-Egyptian Condominium - which was funding the Sudan Government; and, in turn, the localized necessity of the self-financing mandate, an essential ideological proviso from Grey to Lugard. Thus the British Government was operating within the paradigm of its strategic and economic considerations - which, in the aggregate, motivated the development of Gezira. It is true that, through the process of land settlement and the sale of tenancies, a formal money economy was introduced and elaborated and land ownership emphasized - all in-roads and outlets towards social development that were cleared by virtue of the project. But social development was less a conscious decision on the part of the Europeans than the epiphenomenal byproduct of the imperatives of Empire.

This largely organic process soon withered on the imperial vine when, what tentative - if tangential - steps had been taken were exposed to the caustic effects of the Great Depression. ${ }^{77}$ As had happened with the First World War, the fiscal constraints imposed by the Depression ruled out any question of social experimentation - it was enough just to keep the Scheme from foundering. There is something of a tragedy in all of this, something more than just ironic for, at the precise moment when an emergent proprietary class was being integrated into the global

\footnotetext{
${ }^{77}$ Gaitskell, Gezira, 203.
} 
market economy, it collapsed, bringing down the house modernity had built. If that wasn't enough, the effects of the Depression were intensified by an "unprecedented low yield" in cotton as both profits and prices fell - effectively stripping the notion of the tenant farmer as a newly emancipated individual with a rising standard of living of its veneer, revealing it as little more than ephemera. ${ }^{78}$

As the Depression shattered the confidence of the tenants, attention was drawn to a significant difference of opinion concerning the administration of the Scheme itself. Fissures appeared between the S.P.S. and the Sudan Government when the question of the administration of the Scheme was raised within the framework of indirect rule. For its part, the S.P.S. feared that, by relying on an outmoded system of tribal aristocracy, indirect rule would undermine the project's efficiency and hit it where it mattered most: its purse. ${ }^{79}$ The S.P.S. therefore proved intractable, bogging the Government down in an ideological quagmire that imposed some rather daunting circular logic. It ran something like this: an essential part of the administration of the Scheme was its reliance on technical education or training - "social resources" that imbued people with respectability by giving them access to steady supplies of money in the form of salary. ${ }^{80}$ If the people of Gezira were to be more than simply producers in the Scheme, were to be somehow more closely associated with the management of the project, they would necessarily have to be trained to do so. The implication here is that access to education inherently saved the Government money while, at the same time, it inadvertently fostered social development. On paper, at least, these circumstances made it desirable to impose indirect rule on the Gezira but, by doing so, the Government - which insisted on gradually training up the tenants - risked imperiling the operation at precisely the time when cotton yields were poor, locusts were dense

\footnotetext{
${ }^{78}$ Reports on the Finances, Administration and Condition of the Sudan in 1931, Cmd. 4159, at 67.

${ }^{79}$ Gaitskell, Gezira, 203.

${ }^{80}$ Barnett, Gezira Scheme, 47.
} 
on the ground, and the global economy in a tailspin. This, of course, took all the interested parties back to square one: force indirect rule on the Scheme while the Government was retrenching and making satisfactory progress with devolution elsewhere, or wait out the Depression $?^{81}$

In the end, they need not have worried for the economics of the Depression made the decision for them. It wasn't until after the recovery years of $1934-38$ that fundamental changes were enacted to the administration of Gezira which created a purposefully directed strategy that embedded into the project a social development schema. ${ }^{82}$ Until then, the project remained an ideological anomaly, an island of direct rule in an otherwise sea of devolution. ${ }^{83}$ But, intrinsically, the S.P.S.'s objections concerning the Scheme's loss of efficiency during the Depression were only as good as the Depression was long and, in the event, by the late 1930s, recovery had all but mooted the Syndicate's protestations. Though it is hard to imagine the S.P.S. did not know that the economic ground on which it stood had shifted beneath them as the effects of the Depression waned, one can suppose that it was slow to recognize that an ideological change had taken place, one that morphed the ground from solid to quicksand.

And indeed perhaps it was slow to detect at first, for events in the mid- to late-1930s were largely eclipsed by efforts at recovery. Nevertheless, crucial changes were afoot. Recall that defining the relationship between the metropole and her colonies - that is, what role the colonies played on the stage of empire - was Joseph Chamberlain's Imperial Estates Doctrine. For over

\footnotetext{
${ }^{81}$ Reports on the Finances, Administration and Condition of the Sudan in 1931, Cmd. 4159 at $66-68$ and $3-4$.

${ }^{82}$ Report by the Governor-General on the Administration, Finances and Conditions of the Sudan in 1938, Cmd. 6139, at 3 .

${ }^{83}$ Notwithstanding this, Sudanization proceeded apace. Indeed, the Governor-General's reports between 1938 and 1941 show a marked increase in the total number of educated, Northern Sudanese in Government employ. In 1938, the number went from 4,328 Sudanese staffers to 4,607, forming nearly $75 \%$ of the total classified staff of the Government. By 1941, 80\% of the total classified staff were Sudanese - this, in contrast to $50.9 \%$ of overall staff in 1930. See in the Report by the Governor-General on the Administration, Finances and Conditions of the Sudan in 1938 and the Report on the Administration of the Sudan for the Years 1939 - 41 (inclusive).
} 
thirty years, Chamberlain's constructive imperialism was the mechanism by which the possessions identified themselves with - and were identified by - London. In the wake of the Great Depression, however, this doctrine became increasingly threatened, particularly amidst growing challenges to the colonial project, both from the center as well as the periphery. In the colonies, these challenges ran the gamut: economically, local indigenous reaction to cyclical economic downturns during the recovery period led to massive strikes and protests across the Empire, from St. Kitts to Northern Rhodesia; socially and ecologically, expanding indigenous populations threw starkly into contrast the capacity and longevity of fixed agriculture versus traditional shifting cultivation techniques. Added to this is what Hodge has referred to as a "neoMalthusian crisis" in the seat of empire, one characterized by a depopulation panic spurred by the decline in Britain's birth rate - a trend well underway during the Depression years. Indeed, statistics showed a striking shift in the average size of the British family, for the proportion of families with five or more children fell from 27 percent before the First World War to fewer than 10 percent in the 1930s. ${ }^{84}$ At the same time, colonial populations surged. In the aggregate, these conditions provoked calls for an aggressive campaign of state intervention into colonial societies.

At the heart of the issue was a question of responsibility. Since, in one form or another, these conditions were linked to British interference, was it not now the job of Britain to organize new societies capable of dealing with the changes wrought by modernity? ${ }^{85}$ If this argument were to be accepted, it posed a fundamental problem: how could Britain, which lacked a comprehensive understanding of her Empire, possibly outline a program for its organization? Thus, while these circumstances underscored the need for Britain to better understand her empire, they had the affect of considerably problematizing the question. It is from this crucible

\footnotetext{
${ }^{84}$ Hodge, Triumph, $182-3$.

85 Ibid.
} 
that emerged Lord Hailey's African Survey and a sweeping, total revision of the colonial project that was, in the words of the Sudan's Civil Secretary Douglas Newbold, nothing short of a "social revolution."

${ }^{86}$ Henderson, Newbold, 130. The citation comes from a letter Newbold wrote in February 1940 to Christopher Cox, Director of Education in the Sudan, regarding Hailey's forthcoming visit to the Sudan. 


\section{Chapter Three: \\ Towards Social Development}

Hailey's "social revolution" signaled a new trend in British colonial thought, one in which the colonial project's ostensible purpose pivoted away from the traditional, paternalistic methodology built into the framework of "trusteeship." ${ }^{87}$ Instead, beginning in the late-1930s, the metropole adopted a more ameliorative approach, something resembling the modern, forward-looking notion of "partnership." 98 This revolution of the colonial space, this ideological sea-change came soon after the promulgation of the African Survey in 1938 and had the effect of transforming the overarching objectives of the colonial project. No longer would administration be subsumed by the manifold exigencies inspired by the maintenance of law and order; rather, as the need for pacification had largely subsided throughout the realm and at least partly in response to the popular unrest during the recovery years, the paramount concern became the social emergence of indigenous peoples - to be achieved, it was supposed, by virtue of the mechanisms of scientific and social research. ${ }^{89}$

Some two years later, Parliament legislated this doctrinal deviation when it passed the Colonial Development and Welfare (C.D.\&W.) Act of 1940, which effectively superseded the Colonial Development Act (C.D.A.) of 1929. Whereas Hailey’s Survey can be said to have provided the ideological stimulus for development, the C.D.\&W. Act transformed the rhetoric of social policy into reality by adding the crucial element of capital. Indeed, not only did the Act commit the British Government to the subsidization of projects designed to improve colonial living standards, but it also provided for an annual outlay of up to $£ 500,000$ for colonial research, which the British Government used to fund the Colonial Research Committee - itself chaired by

\footnotetext{
${ }^{87}$ Lee, Colonial Development, 45.

${ }^{88}$ Gaitskell, Gezira, 222.

${ }^{89}$ Lee, Colonial Development, 78.
} 
Lord Hailey. ${ }^{90}$ By virtue of these grants, the C.D.\&W. Act explicitly acknowledged "that social and economic progress in the colonial areas required distinctive and separate treatment." ${ }^{91}$ It seemed Great Britain, once the Empire of Self-Sufficiency, had become the Empire of Good Intentions. $^{92}$

For the British Sudan, however, there was a glaring problem in all of this. Recall that the framework for the relationship between the Sudan and London was shaped by the statutes and provisions outlined in the Anglo-Egyptian Condominium Agreement of 1899. Under that Agreement, Britain administered Egypt and the Sudan as a single entity - with the latter being a kind of exotic appanage of the former. Though this arrangement came to an end with Britain's unilateral abrogation of the Condominium Agreement in 1922, it was re-imposed in 1936 with the Anglo-Egyptian Treaty of Alliance - a curiously paternalistic document, given the apparent trajectory of imperial policy away from paternalism. Be that as it may, the treaty reaffirmed the essential paradigm of metropolitan governance: that is, oversight of the Sudan fell within the purview of the Foreign Office - not the Colonial Office. ${ }^{93}$

As far as the C.D.\&W. Act was concerned, this organizational nuance made all the difference. Since the C.O. played no role in its administration, the Sudan could not tap the Act's $£ 120$ million development fund - a conditionality that was, in effect, a perpetuation of an earlier restriction imposed under the Colonial Development Fund established by the C.D.A. of 1929. As so often had been the case, Khartoum found itself once again on the short-end of the funding stick. $^{94}$ Awareness of this did nothing whatsoever to take the sting out of the wasp of persistent

\footnotetext{
${ }^{90}$ Hodge, Triumph, 180 and Lee, Colonial Development, 35.

${ }^{91}$ Lee, Colonial Development, 84.

${ }^{92}$ Simon Schama, A History of Britain, Volume III: The Fate of Empire (London: BBC Books, 2002),

93 'Abdel Rahim, Imperialism and Nationalism, 85.

${ }^{94}$ Harley V. Usill, “Britain's Achievement in the Sudan,” World Affairs 110, No. 4 (1947): 292.
} 262. 
exclusion, however, and Civil Secretary Douglas Newbold complained bitterly about it: "[The Sudanese] are loyal, witness 1914 - 18 and 1940 - 44, but to what? A remote abstraction, a Condominium. And as regards butter, the Egyptians dangle large pats in front of them while Britain legalistically denies them Imperial Preference, eligibility for Colonial Development Fund, etc. Little wonder that some of the Sudanese intelligentsia say 'We admire British culture and justice, but what do we get out of the British connection?"95 In the event, the British Government recognized that some sort of allowance had to be made for those territories that did not fall under the aegis of the C.O. In the case of the British Sudan, this recognition eventually translated into a $£ 2$ million grant-in-aid to fund further development. ${ }^{96}$

Notwithstanding the finer points of financing a vast, globalized development program which, if we are to judge from the resentful tone of Newbold's Aide Memoire, inspired strong emotions - it was evident that the British Government had become preoccupied with improving the conditions of the people who called the Empire home. So much so, in fact, that it enacted nothing less than a total revision of its social development agenda. The question that needs to be asked, of course, is why? After all, the shift away from trusteeship did not occur in an imperial vacuum, the decisions made leading up to it were not isolated and divorced from the colonial endeavor. What, then, was the context, the milieu that motivated the change? In the end, it was largely the product of three events, each of which dramatically pressurized the colonial space. It began with the Great Depression and its Empire-wide implications - which, in the aggregate, gave rise to the welfare state, an essential pillar of which was social development. Then, in 1938/39, the Royal Commission on the West Indies was set up to investigate strikes, lock-outs, and general unrest among the laboring populations in the West Indies, the Rhodesian Copperbelt,

\footnotetext{
${ }^{95}$ Henderson, Letters, 399. Emphasis Newbold's.

${ }^{96}$ Usill, "Britain's Achievement," 292.
} 
and in the plantations of Burma and Malaya - marking a major point of departure in the conversion of the Colonial Service to a development policy more in line with the welfare of colonial peoples. ${ }^{97}$ To this was added the Second World War, a signally-important, if contradictory, turning point for the Empire: on the one hand, the War catalyzed a development and welfare strategy that promoted social emergence. On the other hand, it drained the empire of its resources - both human and financial - and necessarily delayed the program's full implementation. At the same time, it stressed the imperial supply chain, which dovetailed into an increased demand for colonial resources in the name of imperial and national interests. ${ }^{98}$

As the post-Depression, wartime rhetoric of social development was ratcheted up in London, it found a direct corollary in the Sudan: "Schedule X," a pilot scheme for social development in the Gezira. ${ }^{99}$ Promulgated by the Gezira Advisory Board ${ }^{100}$ in 1940 , the Schedule formalized the Government's social development program by setting forth an agenda to secure the concomitant social desiderata - that is, it acted as the blueprint for a program of devolution of authority in the field as well as a directed program of agricultural education. ${ }^{101}$ This was all well and good, but it was not the first time the Sudan had been invited to the

\footnotetext{
${ }^{97}$ Lee, Colonial Development, 45. Before the House of Commons on February 20, 1940, Secretary of State for the Colonies Malcolm MacDonald discussed the findings of the Commission. In his remarks, he alludes to provisions that would, very shortly, be included in the as-yet-unlegislated C.D.\&W. Act of 1940. "The Government's statement of policy covers a much wider field than the West Indies alone. It contains the conclusions from a close examination into Colonial problems which the Government had been conducting for some time before the war, and it provides for an important extension of their Colonial policy. In future greatly increased provision will be made for development and welfare throughout the Colonial Empire. As hon. Members will be aware, the Colonial Development Fund of maximum of $£ 1,000,000$ a year set up ten years ago has proved a very valuable instrument for Colonial development. But it is inadequate both in amount and in scope for the larger purposes which we have now in mind. The Government propose to introduce legislation providing for assistance from United Kingdom funds up to $£ 5,000,000$ a year for Colonial development and welfare, and, in addition, up to $£ 500,000$ a year to assist in the various fields of Colonial research." See at http://hansard.millbanksystems.com/commons/1940/feb/20/west-indies-royal-commissions-report\#column_1165.

${ }^{98}$ Hodge, Triumph, 197.

${ }^{99}$ Gaitskell, Gezira, 208.

${ }^{100}$ Established in 1936, the Gezira Advisory Board was the body responsible for the coordination of Government policy vis-à-vis the Gezira Scheme.

${ }^{101}$ Gaitskell, Gezira, 165 and Henderson, Letters, 516 - 517.
} 
development dance - and been found wanting. Indeed, the notion of devolution remained anathema to the Sudan Plantations Syndicate since its concomitant gospel of indirect rule which called for the training-up of educated Sudanese to assume more active roles in the project - translated into one thing and one thing only: a loss of efficiency. And to anyone remotely familiar with the principles of profit and loss, a voluntary loss of efficiency is counter-intuitive since it raises the specter of a drop in revenue. There was little reason, therefore, to suppose or suspect that the Syndicate's position had changed - yet it, too, was asked to the dance.

For its part, the Government simply recapitulated the position it held during the Great Depression, as articulated by Newbold in a letter to R.C.C. Mayall, Governor of the Blue Nile Province: "[...] unless the Sudanese can soon have more intelligent participation in the Scheme than that of a labourer, we are bound to have trouble."102 In its response, Khartoum did two things to ham-handedly woo the Syndicate: firstly, it addressed the Syndicate's concerns over lost revenue by asserting that any such loss could be partly or wholly made up by the dilution of the Scheme's British staff. Secondly, and for good measure, it tied the extension of the Agreement with the Government to the social development program. In these circumstances, the Syndicate - which had carried the day during the Great Depression - could do little else but be wooed. ${ }^{103}$

Regardless, Schedule X marks a defining moment in the history of social development policy in the Sudan. As such, it is worth reproducing it here:

The Government's general policy is to train up a class of small farmers who, when the concession period is ended, can make the best use of the permanent irrigation system established in the Gezira.

The Government's administrative policy is:

\footnotetext{
${ }^{102}$ Henderson, Letters, 516.

${ }^{103}$ Ibid. and Gaitskell, Gezira, 344 - 353.
} 
(a) The development of an orderly organisation of village communities controlled by headmen selected by themselves.

(b) The devolution of civic and agricultural control of the farmers to agents of this organisation (e.g. agricultural sheikhs) and the use of village and other councils and of native courts to support and enforce the authority of these agents.

(c) The gradual substitution of Sudanese for all non-British employees and eventually the use of Sudanese agriculturalists in the field in an advisory capacity.

The Government's agricultural policy is:

(a) The production of a class of mixed farmers with a permanent stake in the land which they farm. To this end:

(b) The cultivation of food and fodder crops should be given as much importance as the money crop.

(c) Provision should be made for the agricultural education of native agents and selected farmers. ${ }^{104}$

It was, by any measure, a reasonably straightforward document - a redeeming quality that did not, however, immunize it against the imperatives of war. Indeed, war made several aspects of the plan impracticable - at least in the short-term. Firstly, the Sudan Government lacked the machinery to implement a number of the initiatives under the agricultural policy chief among these was the inability of the Department of Agriculture to provide trained Sudanese as field inspectors. With the onset of war, money for such diversions was not forthcoming. Secondly, in spite of the departure of many British inspectors to war service, the process of devolution, begun experimentally in the Hosh region of the Scheme, remained slow - and was in fact shelved entirely until 1943. In the end, during the first few years of the 1940s, Schedule X reflected basically two things: the Empire's growing "developmentalist state" mentality, which had become the handmaiden of social revolution, and the rhetoric that inspired it - little else. ${ }^{105}$ The revolution, it seemed, was to remain one of paper for the foreseeable future.

${ }^{104}$ Gaitskell, Gezira, 208 and Henderson, Letters, 516 - 517. For the purposes of agricultural administration, the Sudan Plantations Syndicate had divided the Gezira Scheme into forty blocks. The Hosh area was chosen because it was an older - and, therefore, more stable - block.

105 Bonneuil, "Development as Experiment," 265. 
Even so, the objectives of self-management had, in fact, become a more conscious ideal, and the war - as is so often the case with conflict - aroused considerable nationalist sentiment among the Sudanese, particularly where the Gezira was concerned. In point of fact, as Newbold noted, there was an "increasing interest" in the Scheme by the educated Sudanese, and it was only a matter of time before the tenants themselves "awoke" to its possibilities. ${ }^{106}$ On the ground, practical stimulus for this came from two directions: the Graduates' Congress and the Atlantic Charter, both of which require some comment. Drafted by Great Britain and the United States and agreed upon by the Allies in 1941, the Atlantic Charter did for the Second World War what Wilson's Fourteen Points did for the First: it provided the ideological bases for nationalists throughout "the Colonial Melting Pot" to canalize their energies toward self-determination. In the Northern Sudan, the affirmation of the right of all peoples to choose their own government seems to have been taken as the unequivocal declaration of the policy, which translated into a marked increase in the urgency of building up local responsibility. ${ }^{107}$ Meanwhile, in the House of Lords, Hailey was himself inspired by the Atlantic Charter and urged concrete statements about British intentions vis-à-vis representative institutions in the colonies. "Common prudence," he remarked, "forbids us to disregard the more advanced section of opinion, for it is this element which in the long run will determine the attitude of the people towards our administration. ${ }^{, 108}$

This, of course, is where the Sudan's proto-representative Graduates' Congress fits in. Based loosely on the concept and design of the Indian National Congress, the Graduates' Congress was founded in 1938 as an avowedly apolitical group - no doubt largely because Newbold had himself warned the Congress off from politics - of Sudanese graduates of Gordon

\footnotetext{
${ }^{106}$ Henderson, Letters, 516 and Gaitskell, Gezira, 224.

${ }^{107}$ Henderson, Letters, 213.

${ }^{108}$ Ibid., $559-560$.
} 
Memorial College. Broadly-speaking, the Congress's objective was, in the beginning, "to promote the general welfare of the country and its graduates." 109 For its part, the Government seems to have accepted this at face value and assumed that the Congress would behave itself, likening it to "a semi-public organisation interested in philanthropic and public affairs and competent to hold and express opinions on such matters as come within its purview." If we accept this and consider it within the context of the Congress's ostensible "purview" - which, as read, seems decidedly open to interpretation - one can imagine the shock of the naïve and unsuspecting British when, in 1942, the Congress thrust upon them its "Memorandum," which virtually seethed with political rhetoric. Undoubtedly inspired by the Atlantic Charter, the "Memorandum" called for, among other things, "a joint declaration [by the British and Egyptian governments] granting the Sudan, in its geographical boundaries, the right of self-determination, directly after the war," the formation of a Sudanese representative body to approve finance and legislation, "[t]he termination of the Sudan Plantations Syndicate contract at its expiration," and "[t]he carrying out of the principle of the welfare of the Sudanese...."110

The Graduates' Congress's demands were symptomatic of the challenges and opportunities wrought by the war - which the Sudanese thought would make the British more receptive to change. Though the Congress's aggressive demands were rejected outright, and the Graduates duly chastised for their hubris, it was apparent to the Government that the Sudan, like other African dependencies, could not be oblivious to the progressive trends of thought and declarations emanating from Great Britain and the United States. That said, in a note to the Governor's Council, Newbold assessed the situation and made recommendations, which reflected rather appropriately the global state of affairs. Firstly, he noted the importance of the

\footnotetext{
${ }^{109}$ Henderson, Letters, 536 - 537.

${ }^{110}$ Ibid., 540 - 541 and MacMichael, The Sudan, 192.
} 
promulgation of the Atlantic Charter and the consequent commentaries in the world's press and broadcasts; secondly, he cited the influence of Sir Stafford Cripps' "spectacular mission to India, the effect of which was heightened by his passage through the Sudan"; thirdly, he commented on the fall of Malaya and Burma, which led to a number of articles in the British, American, and Dominion Presses that were highly critical of British colonial administration in those areas; and, lastly, he remarked on the Graduates' Congress's "Memorandum" and its demands regarding self-determination. ${ }^{111}$ Newbold concluded that, in order for the Sudan to get "into step with these forces," the Government had to extend the process of devolution, accelerate the Sudanization of the administration, and expedite the creation of an Advisory Council for the Northern Sudanese. ${ }^{112}$

These recommendations bore fruit when, in 1944, "five province councils were formed to assist Governors in their executive duties and to elect members to the Advisory Council for the Northern Sudan," the principles of the Atlantic Charter were fully deployed in the Gezira Scheme by way of the Schedule X conception, which paralleled a comprehensive reorganization that created rural district councils and delegated powers to issue local by-laws. ${ }^{113}$ And, in a move that signaled Khartoum's recognition that the economic necessities motivating the Syndicate were at odds with the notions of advancement and social emergence embedded in the new development policy, the Government decided not to renew its agreement, which was set to expire in $1950 .^{114}$

As important as all these changes were, however, there is a fundamental problem with all of it: one cannot hear the tenants' voices. For whatever reason - be it prejudicial or the fact that

${ }^{111}$ Henderson, Letters, $554-555$.

${ }^{112}$ Gaitskell, Gezira, 222 and Henderson, Letters, 557.

${ }^{113}$ Report on the Administration of the Sudan for the Years 1942 - 1944 (inclusive) (Khartoum: Messrs. McCorquodale \& Co. [Sudan] Ltd., 1947), at 2 and Gaitskell, Gezira, 216.

${ }^{114}$ Gaitskell, Gezira, 216 \& $222-223$. 
no official mechanism existed to elicit their opinions - the tenants were mute. As the Government continued to formulate its social planning agenda, all the decisions were being made for the tenants instead of by them. Perhaps it is not altogether unexpected for the British to behave paternalistically - after all, they had done so for a long time - even though nothing is more at odds with the notion of partnership. On the other hand, what about the Graduates' Congress? Could they do nothing to give the tenants a say? As the body that represented the Sudanese intelligentsia, it is open for debate whether or not the tenants' concerns mattered much to the Congress outside of political considerations - and, anyway, after 1942, the embattled Congress had split into warring factions, a bifurcation from which it never recovered. In the end, it was up to the tenants themselves to make their voices heard and, in 1946, they did so. That year, they "awoke"; that is, they went on strike and demanded that the $£ \mathrm{E} 1.3 \mathrm{M}$ standing in the credit reserve fund (maintained against a possible future slump in the cotton market) be paid out to them forthwith. ${ }^{115}$ They complained, among other things, that they had no idea as to the size of the fund and, in any event, no say in the fund's administration. A Special Gezira Committee for the Advisory Council for the Northern Sudan visited the area and, in its subsequent report, recommended that $£ E 400,000$ be paid out to the tenants. To this, the Government agreed, but it went considerably further. In what were the first concrete steps to associate the tenants of Gezira more closely with the central authority, it "set up the machinery for representation of the tenants in matters particularly affecting their interests as cultivators."

By including the tenants in the formulation of policy, heretofore limited to what the British planned to do and what the Syndicate felt it could reasonably allow - which was, as we have seen, often a source of tension - the Government closed the last gap in the necessary

${ }^{115}$ Gaitskell, Gezira, 224.

${ }^{116}$ Report by the Governor-General on the Administration, Finances and Conditions of the Sudan in 1946, Cmd. 758, at 3. 
triumvirate of social development in the Gezira Scheme. With the end of the Syndicate Agreement in 1950 came a convergence of metropolitan theory and colonial praxis, one in which the Government and the tenants acted together to attain the same goal - a dynamic mediated by Britain's new army of scientific and technical advisers.

It is fitting, then, to consider events in the Gezira during the late-1940s as a kind of ideological cataract, an onward rush of social development that pushed the flotsam and jetsam of colonialism out of its way in a great, transformative surge. This was the point of no return and, perhaps inevitably, as the fulcrum of administration began to pivot away from the British and toward the Northern Sudanese, attention turned to the vast expanse of territory beyond the Nuba Mountains, to the region that the Sudan's Black African population called home: the South. Since the reconquest in 1898/9, the British administered the Southern Sudan with little or no reference to the Northern Arab region. For all practical purposes, it was a territory unto itself; possessed of a culture, religion, and heritage that had more in common with the peoples of the neighboring Belgian Congo than those from the Northern Sudan.

In 1930, the British acknowledged the South's separate identity with the promulgation of its Southern Policy, the ostensible purpose of which was to safeguard the Southern Black African provinces from commercial exploitation at the hands of the Northern Arabs. In effect, Southern Policy institutionalized what had all along been the Government's administrative principle toward the South: benign neglect masquerading as protectionism. This protectionism combined with the remoteness and poverty of the region and with a lack of capital investment by the British on anything beyond bare strategic essentials to produce an economic situation that, "even by African standards, was undeveloped." ${ }^{117}$ Consequently, south of the Nuba Mountains, an

${ }^{117}$ Conrad C. Reining, The Zande Scheme: An Anthropological Case Study of Economic Development in Africa (Evanston: Northwestern University Press, 1966), 141. 
entirely different Sudan existed that was backward and tribalized. As the North democratized, the South lingered on under the paternalism of Native Administration; as the economy of the North modernized and flourished, the South's dilapidated infrastructure stagnated and its provincial economy remained de-linked from world markets. The result was that, for over forty years, the South continued to be a primitive backwater, virtually untouched by modernity.

All this began to change, however, when the Graduates' Congress published its "Memorandum" in May of 1942. Recall that in their manifesto, the Northern Sudanese demanded the right to self-determination within the geographical boundaries of the Sudan. The implications of this were quite probably the most far-reaching of any demand made in the document, for it raised the most fundamental of all questions: What would an independent Sudan look like? Consider further that the "Memorandum" also demanded the "abolition of ordinances on 'closed areas' and the lifting of restrictions placed on trade and on the movement of Sudanese within the Sudan." 118 This was a broadside against the Southern Policy itself, which used the mechanism of closed districts to prevent any intercourse between the Northern and Southern Sudanese - be it political or economic. The proposed abolition of these ordinances raised the bogey of a reconstituted Sudan, one that presumably included the backward Southerners. Did the South, in the end, have a future in an amalgamated Sudan, or was it to be left at the mercy of the "instinctively predatory" Arab North when the British packed up and left $?^{119}$

The answer came in 1943, when Dr. J.D. Tothill, the Director of Agriculture and Forests in the Sudan, submitted a memorandum to Khartoum titled, "An Experiment in the Social Emergence of Indigenous Races in Remote Regions." Based largely on the results of a tour he

\footnotetext{
${ }^{118}$ Henderson, Letters, 541.

${ }^{119}$ Khartoum Despatch, 89. Sudan Archives, Durham (SAD), 664/12/2.
} 
conducted of the South's Equatoria Province in 1939, with minor revisions made in 1942, the goal of the experiment was the "complete social emergence and the social and economic stability of the Zande people." ${ }^{120}$ As designed, the essence of the so-called Zande Scheme was, rather simply, self-sufficiency. Tothill argued that, in order to plan the orderly emergence of the inhabitants of central Africa as "happy, prosperous, literate communities based on agriculture and participating in the benefits of civilization," it was necessary to break through the impasse in development by making them as nearly self-contained as possible. To this end, he proposed an irrigation scheme anchored by the cultivation of cotton, but sustained by a host of other cash crops, including oil palms, coffee, and jute. The key assumption was that, by marketing a sufficient surplus of these goods to obtain the comparatively small amount of money required for the few indispensible imports they would need, it theoretically allowed the Azande to achieve financial independence. ${ }^{121}$

The importance of the economic line of development aside, there was embedded within Tothill's plan a variety of programs meant to foster the social emergence of the Azande people. Included among the more basic and fundamental aims were the betterment of the people's health, by virtue of an improved diet and the elimination of the scourge of malnutrition, and the expansion of their educational opportunities. ${ }^{122}$ It was to be a gradual process, but over the course of several decades the educational system was to be expanded so that eventually 95 percent of the Azande would be literate. The idea was that schooling would be made available to every Zande boy and girl, starting at the "bush level," continuing up through newly-established

${ }^{120}$ William A. Hance, "The Zande Scheme in the Anglo-Egyptian Sudan," Economic Geography 31, no. 2 (1955): 150. http://www.jstor.org.

${ }^{121}$ Reining, Zande, 143.

${ }^{122}$ Minutes of the Ad Hoc Committee: Zande Projects, SAD 664/12/13. 
secondary schools and, ultimately, to the region's first-ever university. ${ }^{123}$ Oversight of all of this was to be vested in the Equatoria Projects Board (E.P.B.), which took its functional cue from its Northern counterpart in the Gezira. As the controlling body, the E.P.B. was to operate the various industries for the benefit of the Azande, from those related to cotton-growing to those associated with the processes of palm oil extraction and soap-making. And, reflecting a kind of lessons-learned from the Gezira experience, Tothill stressed the necessity of encouraging local participation in the Board. Exclusion, it was implicitly acknowledged, would only breed resentment.

The Scheme's emphasis on social and economic development undergirded by a framework of partnership exemplified the essential tenets of Hailey's African Survey and, by extension, the ideological revolution it launched. As such, it represents a stark contrast to the formula of development that inaugurated the Gezira Scheme in 1926. Above all else, irrigation of the Gezira Plain and the cultivation of its "white gold" was an economic/strategic decision, the ultimate goal of which was to shore up the British position in both the Sudan and Egypt. ${ }^{124}$ In planning the Zande Scheme, however, Tothill jettisoned any economic considerations outside of those that contributed to the self-sufficiency of the Azande - the better to insulate them from the volatility of world markets. This principle highlights a significant paradoxical difference between the two schemes: whereas Gezira was intended to integrate the Sudan more fully into the global economy, Zande was designed to keep the people detached from it.

That said, it seems somehow ironic that the first large-scale development experiment in the Southern Sudan should have a purposefully provincial, almost introverted outlook. But the notion of a "development experiment," introverted or otherwise, is a loaded concept. One might

\footnotetext{
${ }^{123}$ Reining, Zande, 144.

${ }^{124}$ Gaitskell, Gezira, 254.
} 
expect such a project - being an experiment - to be a few feddans or acres in size and anchored by a research station which, presumably, made it better to extrapolate the likelihood of success or failure of a larger endeavor. In drafting his plan, however, Tothill set the Zande Scheme up to be the indicator itself - there would be no experimental or pilot research projects, no testing of feasibility like at Barakat and Tayiba in the Gezira Plain. Zande was to be an all-or-nothing undertaking, based largely on the results of cotton-growing in trial plots planted in the Yambio area in $1935 .^{125}$ Whatever else might be said about it, Tothill's plan was certainly bold.

Daring is one thing, but the design of the Zande Scheme raises several basic questions, not least of which is why the Azande? One glance at a map of the Sudan makes it all the more incredible: why place a large, resource-intensive irrigation scheme in an isolated, remote corner of southwestern Sudan, thousands of miles inland, removed from harbors and ports, and outfitted with a rudimentary-at-best infrastructure? And, perhaps even more puzzling, is why specifically the Azande, when no such constituent preciseness was applied to the remarkably successful Gezira Scheme? The answers to these questions are quite simple, it seems. Not only did the industrious Azande occupy a considerable portion of the largest area of good rainfall in the entire Sudan, but they were also the largest Black African community in the South. Such continuity, it was supposed, could only increase the likelihood of the Scheme's success. ${ }^{126}$

All of this was, of course, theoretical, for it must be remembered that Tothill's social emergence experiment was only a blueprint and remained little more than ink on paper until 1944. That year, as the Southern Policy - "or lack of policy," as some administrators bemoaned - came under increasingly heavy criticism from the Northern Sudanese and the Egyptians, the Governor-General Hubert Huddleston convened a meeting of the province governors, the legal,

\footnotetext{
${ }^{125}$ Reining, Zande, 135.

${ }^{126}$ Ibid., 143.
} 
financial, and civil secretaries, and the directors of agriculture, medical, and education to discuss the postwar future of the Southern Sudan. During the meeting, it was reported that, developmentally, the region was "being left further and further behind" the North. In fact, it seemed that for every Northern advance, the South suffered a correlative increase in backwardness. This chronic retrogression was, at the very least, partly the result of British interference in the Sudan, a fact that inspired a keen sense of guilt among a number of officials. ${ }^{127}$ Rather fortuitously, then, the immediate postwar period effectively removed the limiting factors that had made development in the South unlikely: "not only were the funds for development available, but official opinion both in the South and Khartoum seemed more favorable to a firm development policy." 128

These elements converged with the political awakening of the North to encourage the British to adopt a more positive policy in the South. ${ }^{129}$ It was to be an aggressive program that called for a "more intensive and rapid economic and educational development of the Southern Sudan" to be planned and executed. As suggested during the meeting, the program of advancement was to proceed along two parallel paths of expansion, one for education and one for the improvement of communications, "whether by river, road and rail" as well as "any industrial possibilities.” In 1945, Acting Governor-General T.P. Creed submitted his Despatch No. 89 to Lord Killearn, the British High Commissioner in Cairo. ${ }^{130}$ In that document, Creed explained the policy adopted by the Governor-General's Council in the spring of 1944 and emphasized that, "our obvious duty [to the people of the Southern Sudan] is therefore to push ahead as fast as we can with their economic and educational development $[\ldots]$ that these people

${ }^{127}$ Collins, Shadows, 274.

${ }^{128}$ Appendix B, Khartoum Despatch 89, SAD 664/12/9.

${ }^{129}$ Ibid., SAD 664/12/2.

${ }^{130}$ Appendix B, SAD 664/12/9. 
can be equipped to stand up for themselves in the future." He concluded somewhat cautiously that, "a beginning has been made.",131

As was so often the case with the Sudan, however, there was a problem underlying all of this. Adjusting to a new, forward-looking paradigm of social emergence is one thing if the administration knows what direction it's going in. It's altogether something different when the Government is divided over the shape that future should take. Indeed, as attention turned to Tothill's Scheme, submitted some eighteen months prior, Khartoum struggled with whether or not the future of the South rested in a united framework with the North or as a federation along Nigerian lines. ${ }^{132}$ This uncertainty is apparent in Creed's Despatch to Cairo, in which he noted that the comparative backwardness of the Southern Sudanese threatened their future as "East Africans" - implying that the British considered the Sudan's post-colonial configuration as anything but decided. ${ }^{133}$

Ultimately, however, the Scheme's purpose and subsequent design were entrusted to the Ad Hoc Committee on Zande Projects, which convened in the South in February of 1945. Almost immediately, the notion of self-sufficiency - on which Tothill's plan pivoted - was abandoned. The Committee rationalized this by noting that the machinery required to enforce the "total prohibition of all imports" would be "colossal," and therefore costly. It also stressed that there would be a "general dissatisfaction if cheap and otherwise desirable articles available elsewhere in the Sudan or just over the border were denied to the Azande." It was resolved,

131 Appendix B, SAD 664/12/2.

${ }^{132}$ Sir James Robertson, Transition in Africa: From Direct Rule to Independence, A Memoir (London: C. Hurst and Company, 1974), 106.

133 Appendix B, SAD 664/12/2. 
then, that "the principle of self-sufficiency could only be accepted as far as local produce and locally made articles could compete with imported goods.",134

Moreover, the economic imperatives of the E.P.B. sundered ecological considerations. During the first meeting of the Committee, Dr. H. Greene "emphatically warned" of the dangers of erosion risked by the growing of an annual crop such as cotton and went so far as to recommend that its cultivation be postponed. While his concerns were accepted "in principle," they were pushed aside because cotton was seen as the "only industry [...] suitable for immediate adoption as a cash crop by the native [...] which would produce a quick return to the Board with an immediate benefit to the farmer in the shape of cheap cloth of good quality." At the same time, the cultivation of plantation crops - those mentioned by Tothill in his memorandum included coffee, sugar, and oil palms - was jettisoned. In its resolution, the Committee noted that the decision was taken because the Agriculture and Forest Department didn't possess the necessary knowledge of the crops "to ask native cultivators to take them into their local economy." But as such crops were intended to be the bulwark of Tothill's ideal of self-sufficiency, which the Committee had already done away with, the abandonment of their cultivation seems little more than a formality. ${ }^{135}$

By 1946, virtually nothing remained to distinguish the Zande Scheme as a product of Hailey's revolution. Not even education, arguably the key to the social emergence of the Azande, survived the corrosive effects of the uncertainty of the future of the Southern Sudan. Whereas Tothill's design stressed the importance of the spread of education, with universal education - from grade school through secondary school and beyond - being achieved within 30 years, the Committee abandoned the idea and instead suggested that "the proposed expansion of

\footnotetext{
${ }^{134}$ Minutes, SAD 664/12/12 - 13.

${ }^{135}$ Ibid., SAD 664/12/13.
} 
educational facilities for the entire Sudan would provide enough teachers within 28 years for all Zande children to get an education of village school standard." ${ }^{136}$

Within a year, the Zande Scheme was no longer recognizable as a bold experiment in social emergence. Rather, subjected to the imperatives of economics, it had been reconstituted into something resembling the Gezira Scheme of the early twentieth century. Essential to understanding this utter revision of Tothill's idyll is what Creed hinted at in his Despatch: crippling ambiguity and pervasive uncertainty. Indeed, for all its grand rhetoric, the blueprint for Zande was ill-defined in the one area it needed it most: the avowed objectives of the Scheme. Since no one - including Tothill - took the time to define precisely how it was that social emergence was to be achieved, the administration seems to have defaulted to an overwhelmingly organic process nudged in the direction of social emergence by way of economic development. With no quantifiable way to appraise its effectiveness, the success of social emergence in Zande became measurable over time only in terms of the relative happiness of the Azande. ${ }^{137}$ It would be callous, however, to assume that there was nothing more at work here than a sweeping revision inspired by vagueness. Instead, amidst growing ambiguity as to the future of the South, the British saw negotiating the terms of the project as an opportunity to turn the Zande Scheme into an economic engine that could, in time, provide the necessary revenue to finance the South as an independent state - should that be the eventual outcome of events in the North. ${ }^{138}$ Considered within the framework of these countervailing tendencies, then, it is not surprising that the Scheme's configuration changed and left little room for immediate social development.

\footnotetext{
${ }^{136}$ Minutes, SAD 664/12/14 and Reining, Zande, 151.

${ }^{137}$ Letter from Martin W. Wilmington to Mr. Bayoumi, Department of Agriculture, Khartoum, SAD

${ }^{138}$ Robertson, Transition, 105.
} $929 / 9 / 27$. 
Nevertheless, it would likewise be a mistake to assume that this ambiguity was specific to the Sudan. Instead, the transformation of the Zande Scheme was symptomatic of larger, Empirewide uncertainties stimulated by the exigencies of postwar reconstruction. Indeed, as Hodge has observed, the irony of the period is that, just as the war and the immediate postwar years renewed pressures for the more intensive utilization of colonial resources, the new development paradigm obliged the British to foster the social emergence of indigenous peoples. The contradictions inspired by this administrative schizophrenia manifested themselves in the caustic interstices between colonial theory and practice, itself the unstable point of genesis for projects like Zande as well as the Tanganyika groundnut scheme. ${ }^{139}$ Confronted by these incongruities and disconnects, colonial governments from Nigeria to Malaya struggled with balancing raising colonial living standards and welfare with responding to the pressures of metropolitan needs - all to varying degrees of success. ${ }^{140}$

As the Sudan Government worked to reconcile these dichotomies in Zande, Khartoum was buffeted by a series of events that increasingly pressurized the British position in the South. First among these was the failed renegotiation of the Anglo-Egyptian Treaty of 1936. As codomini under that agreement, Egypt and Britain enjoyed a relatively harmonious relationship albeit one punctuated by periods of discord, such as that which followed the Egyptian Revolution of 1919. The renegotiation of the 1936 Agreement, initiated by the Egyptian Government in 1945, presented a somewhat different dynamic. After a months-long delay, partly attributable to the time it took London to prepare for postwar government policies, talks began in April 1946. Soon thereafter, positions hardened and negotiations foundered on a fundamental point of contention: Sudanese sovereignty. The overarching disagreement manifested itself in the

\footnotetext{
${ }^{139}$ Lee, Colonial Development, 134.

${ }^{140}$ Hodge, Triumph, 230-231.
} 
interpretation of an essential clause concerning the future prospect of Sudanese independence.

Given its significance, the "draft Sudan protocol" - the so-called Sidki-Bevin Agreement - is worth reproducing here:

The policy which the High Contracting parties undertake to follow in the Sudan, within the framework of the unity of the Sudan and Egypt under the common crown of Egypt, will have for its essential objective to assure the wellbeing of the Sudanese, the development of their interests and their active preparations for self-government and consequently the exercise of the right to choose the future status of the Sudan. Until the High Contracting parties can in full common agreement realise this latter objective after consultation with the Sudanese, the Agreement of 1899 will continue and article 11 of the Treaty of $1936 \ldots$ will remain in force. ${ }^{141}$

As written, the clause was clearly open to interpretation - and each codomini did so according to its own needs. From the Egyptian perspective, it meant that the King of Egypt was also the King of the Sudan. The British, however, interpreted it to mean that the "Egyptians were for the first time conceding the right of self-government and eventual self-determination to the Sudan." ${ }^{142}$ As the discussions degenerated into a stalemate over semantics, negotiations came to an abrupt halt. Hoping to bring an end to the debate, which had translated into unrest in the streets of Cairo, Governor-General Huddleston secured affirmation of the British interpretation of the clause from the Prime Minister's Office in London. It read, in part, "His Majesty's Government....are determined that nothing shall be permitted to deflect the Sudan Government, whose constitution and powers remain unaltered by the recent conversations, from the task to which that Government have applied themselves - the preparation of the Sudanese for self-government and for the task of choosing freely what their future status should be."143

\footnotetext{
${ }^{141}$ Robertson, Transition, 96 and MacMichael, The Sudan, 195.

${ }^{142}$ Robertson, Transition, 93 - 99.

${ }^{143}$ MacMichael, The Sudan, 197.
} 
This, of course, failed to placate the Egyptian Government which had, by the end of 1946, broken off negotiations. Instead, on January 26, 1947, Cairo announced that it would take "the whole question of Egypt and the Sudan to the United Nations"- which had moved to temporary headquarters at Lake Success in New York. The subsequent meeting before the Security Council proved largely unsympathetic toward the Egyptian Government, which listed among its demands "the total and complete evacuation of British troops from Egypt, including the Sudan', and 'the termination of the present administrative regime." In its response, the Security Council assumed a noncommittal position, but nevertheless urged caution: "[I]t is difficult for the Security Council to make a decision of any kind now.... We do not know what the wishes of the Sudanese people are nor" their aspirations. ${ }^{144}$ The Council adjourned without adopting any of the major resolutions and instead encouraged the parties to resume negotiations - all to no avail. Though Cairo may not have achieved its hoped-for ruling, the dispute between the codomini managed to do one thing: having raised the issue in what was arguably the world's largest global forum, the notion of Sudanese independence had, for a brief time, taken center stage. $^{145}$

The discussions at Lake Success signaled the high watermark of the growing interest of politically-conscious Sudanese in external affairs, an otherwise natural and predominant feature of the postwar years. In time, this gave place to the concentration of their attention on matters of far-reaching importance within their own country. This shortening of focus to affairs at home in no way obscured the watchfulness of all political elements - particularly in light of the dissolution of the British Raj - on external developments; but, on the whole, these took second place to their intense solicitude for internal developments which culminated in the final session

\footnotetext{
${ }^{144}$ MacMichael, The Sudan, 200 - 201.

${ }^{145}$ Ibid., 202.
} 
of the Advisory Council for the Northern Sudan and the promulgation of the Executive Council and Legislative Assembly Ordinance in June of $1948 .{ }^{146}$

The momentum toward independence had by this time become inexorable and the corollary of the concomitant political imperatives found expression in a series of events. First, the British abrogated the Southern Policy, a seismic change in administration that signaled one thing: the Government was no longer entertaining the notion of a federated Sudan; no paradigm for advancement was being considered outside the framework of unity. More importantly, however, was a necessary emphasis on economic development, lest the Southerners face virtual enslavement at the hands of the Northern Arabs. This found resonance in a subsequent event: the funding of a massive development program. This presents an essential paradox, since it would only be by virtue of capital provided by the North that the South would be able to perpetuate its development goals beyond 1951 - the expiry date of the Government's funded development period. ${ }^{147}$ Civil Secretary James Robertson pointed out the implications of such an arrangement in a note to the Governor-General's Council: "if the Northern Sudanese are to be asked to spend nearly $£ \mathrm{E} 900,000$ a year on the South they are surely entitled to some say in its administration." ${ }^{148}$ This new reality caused the British to shed their illusions: there would no longer be any ambiguity as to the future configuration of the Sudan.

As Khartoum readied for unification, work proceeded apace on key features of the Zande Scheme, including the construction of sawmills at Kateri, Gilo, and Loka in Yambio District. All-weather roads were built - largely through the use of conscripted Azande labor - to link the principal southern towns and permits to trade were now given to anyone who could meet the

${ }^{146}$ Report on the Administration of the Sudan in 1948 (Khartoum: Messrs. McCorquodale \& Co. [Sudan] Ltd., 1950), at 1.

${ }^{147}$ Hance, "The Zande Scheme," 150.

${ }^{148}$ Robertson, Transition, 109. 
commercial requirements. ${ }^{149}$ These, however, were all for naught without the fulfillment of the most significant aspect of the project: the resettlement of the Azande. Unlike in the Gezira, where the Government encouraged tenants - Greek, Egyptian, Sudanese, and Syrian alike - to settle the plain through a decades-long process of land settlement, the British uprooted over one hundred thousand Azande and transplanted them from the rural, tribal homesteads around which they had organized society to a grid-pattern settlement outlined with roads and dotted with houses. ${ }^{150}$ The effects of this process on the traditions and social life of the Azande were devastating. Indeed, the rubric of modern social emergence reckoned little with the fabric of traditional society and its corrosive effects undermined two mutually-supporting aspects of Azande culture: the arrangement of homesteads and the patron-client relationship. By virtue of its design, the Scheme divided up the Azande and arbitrarily segregated them into units framed by dwellings, effectively destroying the social organization of the Azande by attacking it where it was weakest: the grouping of homesteads. ${ }^{151}$ In so doing, the British broke up extended families, fragmenting the superstructure of relations that kept the Azande economically and socially sound. Inherently, this process also physically de-linked the clients (the tribesmen) from their patrons (the chiefs or headmen), a challenge made all the worse by the monetization of the economy. For, necessarily, the Scheme overwrote the imperatives of the Azande barter economy, typically the engine that kept such indigenous African tribes running, with the mechanism of cash money. Instead of cattle, land, and foodstuffs allocated by the headmen, the principle of reciprocity became vested in the essential - and alien - machinery of the Scheme itself: profit and loss. ${ }^{152}$ Within this new schema, the paramount chiefs were replaced by

\footnotetext{
${ }^{149}$ Collins, Shadows, 63 - 64 and Reining, Zande, $163-164$.

${ }^{150}$ J.W.G. Wyld, Aide Memoire to the Zande Scheme and notes on progress, SAD 779/5/17.

${ }^{151}$ Reining, Zande, 129.

${ }^{152}$ Ibid.
} 
bureaucrats and technicians and the interpersonal network of the Azande obliterated, effectively exploding the highly personal elements of the patron-client dynamic and hitting the Scheme where it mattered most: production. ${ }^{153}$

These conditions were articulated in a letter written in 1954 by Martin W. Wilmington, an eyewitness to the Scheme. His correspondence, addressed to the Department of Agriculture, presents an excellent comparison of the practice of the Zande Scheme with that of the theory of its underlying social development principles. "While no visitor can help but admire the considerable technical achievements of the Scheme," he observed, "there seems to be too much emphasis on ostentatious technology and not enough on economics and social welfare." $\mathrm{He}$ continued, "There is much talk about managerial efficiency and budget balancing but little emphasis on economic policy, social welfare, and progress statistics showing the 'social' rather than the financial yield of the project." ${ }^{, 154} \mathrm{He}$ underscored this with an observation regarding the project's personnel. "One would presume that key positions in the execution of a scheme designed to produce 'social emergence' would be held by economists and social workers. In Zande, the key men are business managers and agricultural inspectors whose concern with the larger social and economic implications of the project must, by necessity, remain a by-product of their work." ${ }^{155}$ At the same time, the Sudan Government had done little to set up schools and “other paraphernalia of civilization" to further the social development goals of the project. ${ }^{156}$

At issue here is the structure nourished by the E.P.B., the charter of which had been reinterpreted so that the social emergence of the Azande was to be realized only after the

\footnotetext{
${ }^{153}$ Reining, Zande, 180.

${ }^{154}$ Wilmington to Bayoumi, SAD 929/9/28.

155 Ibid., SAD 929/9/29.

156 Ibid., SAD 929/9/30.
} 
commercial program of the Scheme had provided the means. ${ }^{157}$ This manifested itself in a growing distance of policy between the Scheme's trading and production divisions - which became two separate entities related only through their headquarters, which were some 350 miles apart. This, coupled with a lack of good local distribution channels, translated into a bewildering state of affairs on the ground. Indeed, whereas the products manufactured by the Azande found little interest locally due to relatively high prices (insofar as they compared to products sold by Japanese and Indian merchants in the area), they generated a great deal of interest elsewhere due to a comparatively low price for otherwise high quality goods. This was far from an ideal development since the price Azande cotton fetched in Khartoum was considerably lower than that purchased locally. For the Azande, this meant one thing: little monetary return for their labors. As their dissatisfaction grew, progressively lower crop yields combined with the lack of communal solidarity to signal the terminal decline of the project - less than five years into its operation. $^{158}$

In the end, perhaps the best that can be said of the Zande Scheme is that it was a good idea on paper. Imbued with the intentions inspired by Hailey's African Survey, Tothill's aspirations were nothing if not bold. Admittedly, its idyllic design had serious flaws - it's hard to imagine any government nowadays approving a project the size and scale of Zande without so much as a long-term pilot program to justify the cost - but perhaps most importantly it lacked a fundamentally crucial element, one that Gezira had in hindsight unknowingly enjoyed: cohesiveness of policy. Indeed, just as the Zande Scheme began its downward spiral, its northern counterpart reached a sort of apogee in social development planning and legislation. In 1950, some four years before Martin W. Wilmington wrote his letter expressing his concerns

\footnotetext{
${ }^{157}$ Minutes, SAD 664/12/13 and Reining, Zande, 157.

${ }^{158}$ Reining, Zande, 171.
} 
about Zande, the Sudan Legislative Assembly in Khartoum promulgated the precedent-setting Gezira Scheme Ordinance, which became the basis of a new organization of the project. The Ordinance called for the Sudan Gezira Board, which replaced the outgoing Syndicate as the administrative organ of the Scheme, to promote social development by any means, "having as [the] main object the benefit of the tenants and other persons living in the Scheme area."159 To achieve this goal, the Ordinance established two bodies: firstly, a Social Development Committee with responsibility for the execution of social development. Secondly, a Gezira Local Committee composed of representatives of the tenants, local government, and departments, under the chairmanship of the Governor of the Blue Nile Province. "This body was to submit to the Gezira Board the advice of those living in the Gezira on all matters affecting the welfare of the inhabitants and to make recommendations concerning the allocation of funds available for social development." ${ }^{160}$ A similar body, the Zande District Local Advisory Committee (Z.D.L.A.C.), was formed in the South, but by 1951 its discussions had degenerated into repetition of previous meetings. It was soon abolished due to costly ineffectiveness and though a Social Development Committee was suggested to replace it, the idea never gained traction partly because of the confusion over how to achieve social emergence. ${ }^{161}$

Above and beyond the formation of committees, the Gezira Scheme Ordinance did something entirely new: using money the Board derived from the sale of cotton, it established a fund specifically set aside for social development activities and embedded into the project's management the essential element of tenant cooperation. These changes effectively crystallized

\footnotetext{
${ }^{159}$ Gaitskell, Gezira, 250.

${ }^{160}$ Ibid., 251.

${ }^{161}$ Reining, Zande, $199-200$.
} 
the Gezira Scheme as a model for future endeavors and would greatly influence tenancy arrangements in projects like Kenya’s Mwea Scheme. ${ }^{162}$

This is the inheritance of Gezira, started during the austere early days of the British colonial mission in the Sudan and slowly transformed into a pioneering mechanism of economic and social development. Today, it encompasses 2.1 million feddans and remains operational, some 85 years after the Sennar Dam was completed in $1926 .{ }^{163}$ In contrast to this, the Zande Scheme - a product of the experimentalist mindset that permeated imperial thinking from the 1930s onwards - stands as a colossal failure. But when Zande and the development of the South came to the forefront of the Sudan Government's political agenda - in the closing years of the Second World War - the Lame Leviathan was already in a critical condition. Weakened by the War and undermined by its own rhetoric of self-determination, little could truly be done to resuscitate its mission in the South short of handing it over in toto to the North. In this respect, Zande as deployed in the far southwestern corner of the Sudan represents a kind of confused last gasp; one final exhalation in the Sudan of an empire that struggled with its legacy even as it accepted the inevitability of its own self-liquidation.

${ }^{162}$ Maurits W. Ersten, "Controlling the farmer: colonial and post-colonial irrigation interventions in Africa," The Journal for Transdisciplinary Research in Southern Africa 4, No. 1 (2008): 221 - 224.

${ }^{163}$ Ibid., 216. 


\section{Chapter Four: \\ Towards Independence}

Perhaps the broadest conclusion that can be drawn from an appraisal of these circumstances is that Hailey's ideological revolution left an arguably mixed legacy in the British Sudan. Fundamentally, the African Survey provided the foundational ethos that, when catalyzed by the Depression and the Second World War, shifted the objectives of colonial administration away from responsibility for law and order and toward a concern for the social development of indigenous peoples. ${ }^{164}$ In this respect, the Gezira and Zande Schemes mirror the macrocosm of imperial ideology, albeit writ large on the microcosm of the Sudanese landscape. But even as a microcosm, the projects necessarily reflected the problems of the development agenda. Indeed, throughout the Empire, the British confronted obstacles that made it virtually impossible to close the gap between metropolitan theory and colonial praxis - from money to manpower to indigenous resistance. It was left to the Empire's men-on-the-spot, like Wingate, Newbold, Robertson, and Tothill, to achieve this within the tolerable limits of both London and the Sudanese - which, as we have seen, were often at odds. It was a precarious balance, often teetering on the edge of open conflict.

In a sense, these conditions brought about a day of reckoning for social development in the Southern Sudan, a moment when everything the British had hoped to achieve with social policy broke down. That day came on July 26, 1955, when a riot broke out at Nzara, the industrial hub and manufacturing center of the Zande Scheme. It began when the new Northern Sudanese general manager attempted to remove from the factory a Zande worker who had insulted one of the Northern Sudanese staff earlier in the day. Shortly beforehand, he had likewise dismissed some 300 of the project's workers. Though it was all over in a few weeks,

\footnotetext{
${ }^{164}$ Lee, Colonial Development, 78.
} 
the suppression of the riot by Northern Sudanese soldiers kindled resentment and anger among the Southerners, some of whom had witnessed the melee in which a number of Azande were fatally wounded. It was the equivalent of tossing a lit match into a powder keg for it stoked Southern fears of domination at the hands of the North. Less than a month later the Equatorial Corps mutinied at Torit, which dovetailed into a general uprising throughout Equatoria Province - the opening salvo of the First Sudanese Civil War. ${ }^{165}$

Manifestly, the riot draws attention to an essential aspect of social development: the process of Sudanization. Caught up in the rush to independence between 1951 and 1953, the Sudanese from the Northern Sudan replaced the British administrators of Zande rather more quickly than anyone had expected. The critical flaw in this was that, unfortunately, the Northern Sudanese had neither the competence of the Europeans nor the confidence of the Azande. ${ }^{166}$ The tension this engendered was vented along the lines of the highly charged, ethnicized bifurcation of Sudanese identity.

From the outset, this paper has sought to demonstrate that the evolution of social development in the British Sudan reveals a larger narrative of events, particularly those that triggered ideological changes in Africa during the colonial period. By virtue of this conceit, it has obliged a direct comparative analysis of the two largest and most ambitious irrigation projects ever undertaken by the British in the Sudan: the Gezira and Zande Schemes. In so doing, it fills a somewhat curious gap in the historiography of the British Sudan which, in the end, helps to contextualize later events, such as the Sudanese Civil War. In looking at these two projects and how they were either the product of, or influenced by, the guiding principles of the British colonial endeavor, the interconnected causal relations of their construction have been

\footnotetext{
${ }^{165}$ Reining, Zande, 34 \& 215 and Collins, Shadows, 332.

${ }^{166}$ Collins, Shadows, 332.
} 
made legible, which allows us to trace the evolution of imperial ideology by looking at the social development agenda. Above and beyond this, however, it also reveals how the Gezira Scheme, begun as an engine of economic development designed to make the Sudan self-sufficient, became a model of social emergence that in time influenced future development schemes. Rather interestingly, it also shows how precisely the reverse happened in Zande: Tothill's idyll, once a paragon of social development that pivoted on the fulcrum of self-sufficiency, became the mechanism by which the British attempted - and failed - to secure the economic future of the Southern Sudan. 


\section{Bibliography}

\section{Primary Sources}

Archival Sources

Sudan Archives, Durham University Library, England. (SAD)

Series SAD 664/12/2-3. Khartoum Despatch No. 89, 1945.

Series SAD 664/12/9-10. Appendix B, Enclosure to Khartoum Despatch No. 89, 1945.

Series SAD 664/12/12-27. Minutes of the Ad Hoc Committee: Zande Projects, 1945.

Series SAD 779/5/17. Aide Memoire on the Zande Scheme. Original Correspondence, 1948.

Series SAD 929/9/27-33. Original Correspondence, 1954.

Government Publications

Great Britain

Parliamentary Debates, Commons, $5^{\text {th }}$ series (1913).

Reports on the Finances, Administration and Condition of the Sudan in 1910. Cairo: F. Nimar \& Co., 1911.

Reports on the Finances, Administration and Condition of the Sudan in 1925. Cmd. 2742. London: His Majesty’s Stationery Office (HMSO), 1926.

Reports on the Finances, Administration and Condition of the Sudan in 1931. Cmd. 4159. London: HMSO, 1932.

Reports on the Finances, Administration and Condition of the Sudan in 1933. Cmd. 4668. London: HMSO, 1934.

Report by the Governor-General on the Administration, Finances and Conditions of the Sudan in 1938. Cmd. 6139. London: HMSO, 1939. 
Report on the Administration of the Sudan for the Years 1942 - 1944 (inclusive). Khartoum: Messrs. McCorquodale \& Co. (Sudan) Ltd., 1950.

Report by the Governor-General on the Administration, Finances and Conditions of the Sudan in 1946. Cmd. 7581. London: HMSO, 1947.

Report on the Administration of the Sudan in 1948. Khartoum: Messrs. McCorquodale \& Co. (Sudan) Ltd., 1950.

Books

Gaitskell, Arthur. Gezira: A Story of Development in the Sudan. London: Faber and Faber Limited, 1954.

Grey, Earl Henry. The Colonial Policy of Lord John Russell's Administration, Vol. II. London: Richard Bentley, 1853.

Henderson, K.D. D. The Making of the Modern Sudan: The Life and Letters of Sir Douglas Newbold. London: Faber and Faber Limited, 1953.

Robertson, Sir James. Transition in Africa: From Direct Rule to Independence, A Memoir. London: C. Hurst and Company, 1974.

\section{Secondary Sources}

Books

Barnett, Tony. The Gezira Scheme: An Illusion of Development. London: Frank Cass, 1977.

Collins, Robert O. Shadows in the Grass: Britain in the Southern Sudan, 1918-1956. New Haven: Yale University Press, 1983.

Daly, M.W. The Sirdar: Sir Reginald Wingate and the British Empire in the Middle East. Philadelphia: American Philosophical Society, 1997. 
Lee, J.M. Colonial Development and Good Government. Oxford: Clarendon Press, 1967.

MacMichael, Sir Harold. The Sudan. New York: Frederick A. Praeger, 1955.

McIntyre, John D. The Boycott of the Milner Commission: A Study in Egyptian Nationalism. New York: Peter Lang Publishing, 1985.

Rahim, Muddathir 'Abdel. Imperialism and Nationalism in the Sudan: A study in constitutional and political development, 1899-1956. Khartoum: University Press, 1986.

Reining, Conrad C. The Zande Scheme: An Anthropological Case Study of Economic Development in Africa. Evanston: Northwestern University Press, 1966.

Schama, Simon. A History of Britain, Vol. III: The Fate of Empire. London: BBC Books, 2002.

Sharkey, Heather J. Living with Colonialism: Nationalism and Culture in the Anglo-Egyptian Sudan. Berkeley: University of California Press, 2003.

Wingate, Sir Ronald. Wingate of the Sudan: The Life and Times of General Sir Reginald Wingate, Maker of the Anglo-Egyptian Sudan. London: John Murray, 1955.

\section{Articles and Periodicals}

Bonneuil, Christopher. "Development as Experiment: Science and State Building in Late Colonial and Postcolonial Africa, 1930-1970." Osiris 15, No. 2, Nature and Empire: Science and the Colonial Enterprise (2000): 258-281. http://www.jstor.org.

Coupland, R. "The Hailey Survey." Africa: Journal of the International African Institute 12, No. 1 (1939): 1-11. http://www.jstor.org.

Ersten, Maurits. "Controlling the farmer: colonial and post-colonial irrigation interventions in Africa." The Journal for Transidsciplinary Research in Southern Africa 4, No. 1 (2008): 209-236. 
Hance, William A. "The Zande Scheme in the Anglo-Egyptian Sudan." Economic Geography 31, No. 2 (Apr., 1955): 149-156. http://www.jstor.org.

Pedler, Frederick. "The Rt. Hon. Lord Hailey, OM, GCSI, GCMG, GCIE." African Affairs 68, No. 273 (1969): 344-351. http://www.jstor.org.

Usill, Harley V. "Britain's Achievement in the Sudan.” World Affairs 110, No. 4 (1947): 290292. http://www.jstor.org.

Digitally signed by John $\mathrm{H}$.

$1012 \begin{aligned} & \text { Hagen } \\ & \text { DN: } c n=J \text { ohn H. Hagen, o=West } \\ & \text { Virginia University Libraries, }\end{aligned}$ 